Review

\title{
Sustainable Power Supply Solutions for Off-Grid Base Stations
}

\section{Asma Mohamad Aris ${ }^{1, *}$ and Bahman Shabani ${ }^{2}$}

1 School of Aerospace, Mechanical and Manufacturing Engineering, RMIT University, Room 12, Level 3, Building 57, Carlton VIC 3053, Australia

2 School of Aerospace, Mechanical and Manufacturing Engineering, RMIT University, PO Box 71, Bundoora VIC 3083, Australia; E-Mail: bahman.shabani@rmit.edu.au

* Author to whom correspondence should be addressed; E-Mail: asmamohamadaris@gmail.com; Tel.: +61-468-759-464; Fax: +61-399-258-099.

Academic Editor: Andy Wright

Received: 18 June 2015 / Accepted: 6 September 2015 / Published: 29 September 2015

\begin{abstract}
The telecommunication sector plays a significant role in shaping the global economy and the way people share information and knowledge. At present, the telecommunication sector is liable for its energy consumption and the amount of emissions it emits in the environment. In the context of off-grid telecommunication applications, offgrid base stations (BSs) are commonly used due to their ability to provide radio coverage over a wide geographic area. However, in the past, the off-grid BSs usually relied on emission-intensive power supply solutions such as diesel generators. In this review paper, various types of solutions (including, in particular, the sustainable solutions) for powering BSs are discussed. The key aspects in designing an ideal power supply solution are reviewed, and these mainly include the pre-feasibility study and the thermal management of BSs, which comprise heating and cooling of the BS shelter/cabinets and BS electronic equipment and power supply components. The sizing and optimization approaches used to design the BSs' power supply systems as well as the operational and control strategies adopted to manage the power supply systems are also reviewed in this paper.
\end{abstract}

Keywords: standalone power supply; telecommunication; base station; hydrogen systems; hybrid power supply systems; renewable energy 


\section{Introduction}

The telecommunication sector plays a significant role in shaping the global economy and the way people share information and knowledge. Over the years, the electricity consumption pattern of telecommunication networks has been transformed by fiber-optic communication, the increasing number of global mobile users, and smart devices that require mobile Internet access [1]. Often cited in various papers such as those by Webb [2], Hasan et al. [3], Lambert et al. [4], Kusakana and Vermaak [5], as well as Meo et al. [1], the global annual electricity consumption for the telecommunication sector has increased from 219 TWh in 2007 to 354 TWh in 2012, which corresponds to an annual growth rate of $10 \%$. This projection of global electricity consumption is expected to escalate at an annual additional rate of 10\% between 2013 and 2018, as reported by the Cisco Visual Networking Index: Forecasts and Methodology Report [6]. Accordingly, this makes the telecom operator networks the most electrical energy-intensive consumer within the telecommunication networks that is responsible for the amount of greenhouse gas (GHG) emissions it emits into the environment.

In a comprehensive report on GHG emissions reported by the well-known SMART (Standards, Monitoring, Accounting, Rethink, Transform) 2020, Feshke et al. [7] elaborated that the GHG emissions produced by the telecommunication networks in 2020 will increase by a factor of three when compared to 2007, which means an increase from about $86 \mathrm{Mt} \mathrm{CO}_{2}$ e to $235 \mathrm{Mt} \mathrm{CO}_{2} \mathrm{e}$. Likewise, parallel to the fast-paced growth of electricity consumption of the telecommunication networks, the global mobile data traffic is also expected to grow three times faster than fixed Internet Protocol (IP) traffic between 2013 and 2018; this is while the mobile data traffic is growing faster than average in developing regions such as the Middle East and Africa, followed by Asia Pacific [6]. Figure 1 shows the statistics and projection of subscriptions of mobile telecommunication networks between 2008 and 2017, and this figure illustrates that the demands for wireless and mobile telecommunication networks are rapidly increasing accordingly.

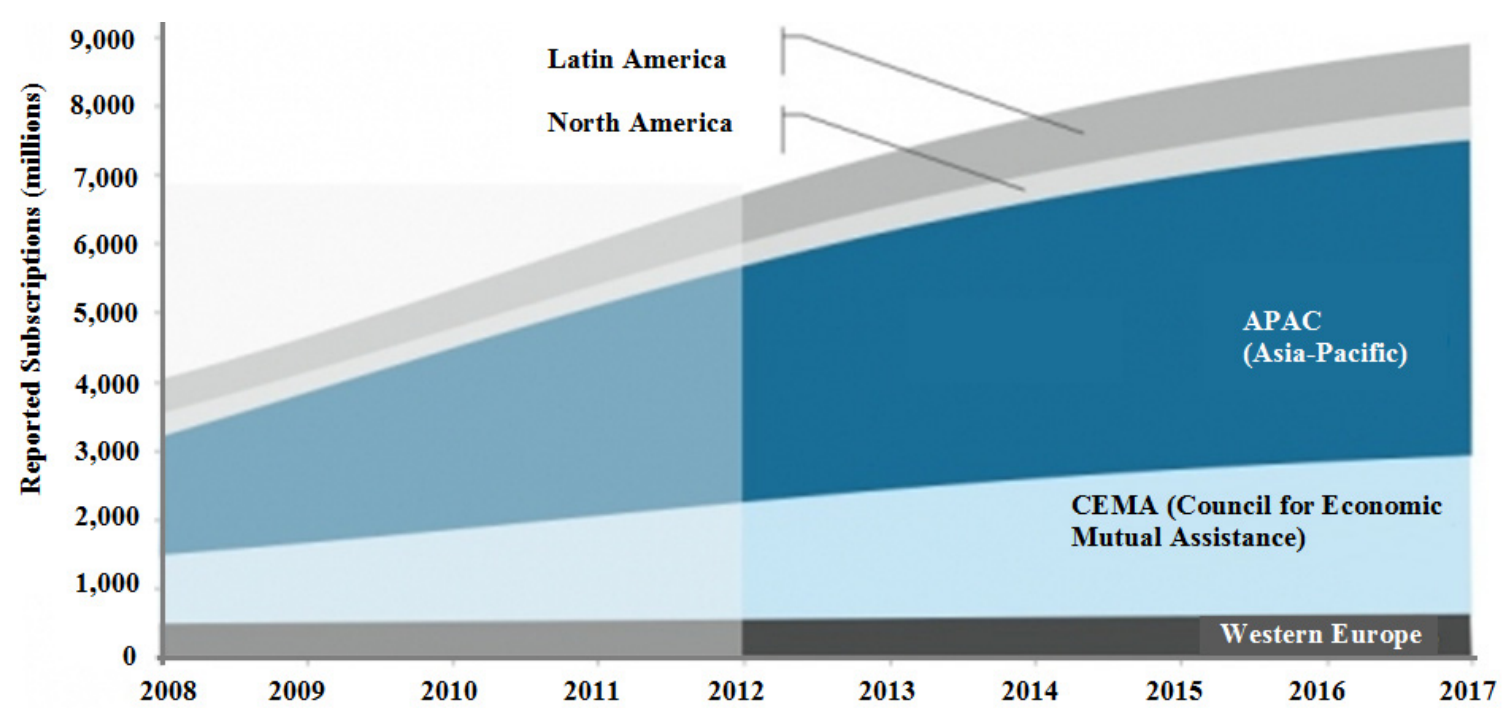

Figure 1. Mobile telecommunication network subscription (2008-2017) [8].

Significantly, the wireless and mobile telecommunication networks are very popular due to their capacity to provide radio coverage over a wide geographic area [9]. This, in particular, is practical for 
remote telecommunication applications where, through the installation of Base Stations (BSs), the development of the wireless and mobile telecommunication networks can be achieved. Furthermore, limitless communication can be made available to mobile users via the wireless and mobile telecommunication networks [10]. Presently, there are several types of BSs that can be found supporting macro, micro, and small (e.g., pico and femto) cells, where each of the cells varies in its specific coverage capability, energy consumption, deployment arrangement, and costs [3,11-13]. In the case when the connection to the electricity grid is unavailable or it is very costly to extend the electricity grid connection, macro BSs are preferable by the telecom operators as compared to the micro and small cells' BSs that are much lower in coverage capability and energy consumption [10,13]. This type of macro BS is also known as the off-grid BS, where its application is suitable for remote telecommunication applications [10].

At present, there are approximately four million macro BS sites installed worldwide, and each of the BSs consumes an average of $25 \mathrm{MWh}$ of electrical energy per year [10]. Based on a report by the Groupe Speciale Mobile Association (GSMA), the growth of macro BSs between 2007 and 2012 almost doubled the number in 2012 compared to 2007, especially in the case of off-grid BSs that are located in Sub-Saharan Africa and South Asia [14]. The numbers also started to increase from 2013 onwards at a rate of $25 \%$ per annum (and the trend is expected to continue), parallel to the increasing traffic demands, especially in developing regions [3]. Despite the wide coverage capability offered by the off-grid BSs, the BSs are the most energy-intensive part of the mobile telecommunication networks which lead to high amounts of GHG emissions and high operational costs [9]. Additionally, the high power consumption by the BSs can also overburden the macrocells and consequently reduce the quality of service (QoS) of the BSs' coverage $[15,16]$. Therefore, the need for the telecom operators to implement energy efficiency solutions is critical in order to reduce their costs and improve the QoS and the GHG emissions associated with the operation of off-grid BS sites.

Diesel generators used to be widely deployed for powering BSs; however, over time, the idea of using diesel generators as a primary or back-up power supply has become less favorable due to the challenges linked to their reliability, availability, high operational and maintenance (O\&M) costs, and their significant environmental impacts [5,17]. In the context of powering off-grid BSs, key features such as the economic, environmental, and social sustainability of BSs are critically important. Hence, methods using renewables coupled with sustainable energy storage solutions are now receiving more attention than before.

In this paper, the focus shall be on off-grid BSs operating in the context of remote telecommunication applications. The conventional and emerging power supply and energy storage solutions as well as the key aspects considered in selecting, sizing, and optimizing them are reviewed. These solutions mainly include diesel generators, sustainable options based on renewables, and hybrid power supply (i.e., Photovoltaic (PV)-wind, PV-diesel-battery, PV-wind-diesel, and PV-fuel cell systems) and energy storage systems. Additionally, the paper also discusses the operating and control strategies used for managing the hybrid power supply and energy storage systems. 


\section{Power Supply and Energy Storage Solutions for Off-Grid Base Stations}

\subsection{Overview}

A reliable and continuous power supply arrangement is an essential requirement to be considered when powering off-grid BSs to ensure that the mobile users and telecom operators do not experience any service outages. Over the years, powering off-grid BS sites has been done using typical power supply solutions such as diesel and petrol generators either alone or together with renewable energy sources (e.g., hybrid PV-diesel power supply systems with or without energy storage). Such power supply solutions are particularly favorable in areas where either extending the grid connection to power the BS site is not economically attractive or the existing grid electricity is not uninterruptedly available to guarantee a continuous power supply [10].

Following the emerging concept of green telecommunication networks, the realization of powering the BS sites using sustainable solutions has started to receive significant attention. Because of that, various studies and developments have been done in order to help the telecom operators to shift away from using diesel generators as their primary power supply solution for BSs. It is being realized that by moving away from diesel generators, the unreliability factors and the high O\&M costs usually associated with this solution can be avoided. In this section, various power supply and energy storage solutions for off-grid BSs are discussed.

\subsection{Diesel Generators}

Diesel generators were among the earliest technologies used as backup or primary power supply solutions for BSs in areas with poor or no access to the main grid [18]. Nordin and Lindemark [19] discussed that for an off-grid BS site application, the sizing of a diesel generator is usually done based on the estimated final capacity of the diesel generator. Hence, all sorts of loads such as linear resistive, capacitive, inductive, non-linear, and linear loads are taken into consideration when sizing the diesel generator.

The key advantage of deploying diesel systems is that the system can be tailored according to the load demand. However, the issue of reliability has always been questionable, and the most obvious factor for the diesel generator is its failure probability at power-up, particularly in cold environments. The common failure figure that is often reported is $0.5 \%$, or 5 out of 1000 start attempts fail [19]. This is enough to put an extra set of diesel generators in place to increase reliability, particularly for applications where $100 \%$ reliability is needed. Although the reliability increases about 200 times by having extra generators on standby, the additional costs associated with this approach may still render this configuration unfavorable for the telecom operators from an economic point of view [19]. Additionally, the rollout of BSs using diesel generators can add a significant amount of GHG emissions to the environment. As reported by Webb [2] of SMART 2020: Enabling the low carbon economy in the information age, the comparison of projected GHG emissions in the telecommunication sector between 2002 and 2020 shows that an increment from about $150 \mathrm{Mt} \mathrm{CO}_{2} \mathrm{e}$ in 2002 to $350 \mathrm{Mt} \mathrm{CO}_{2} \mathrm{e}$ in 2020 is expected. Likewise, from the same report, the mobile network dominates the highest amount of GHG emissions and $103 \mathrm{Mt}^{\mathrm{CO}_{2} \mathrm{e}}$ is estimated to be released in the environment in 2020 if there is no obligatory action taken in order to achieve green telecommunication networks. 
Another major issue associated with deploying the diesel generators for powering off-grid BS sites is that the performance capability of the diesel generators is very low and often inefficient, at about $30 \%$ or less, while the rest of the energy is lost as heat [5]. This, in turn, greatly contributes to the high O\&M costs of the BSs powered by these generators. In a specific case of BSs in remote Kenya, it takes more than 100 trucks to supply enough fuel to the BS sites and a lot of full-time technicians are required to overcome the service outages, leading to various economic disadvantages (e.g., additional unnecessary labor, fuel, and transportation costs) [5]. Another example shows that a telecom operator like Vodacom has to spend more than $\$ 5$ million per year for all of their 157 diesel-powered BS sites (about $\$ 32,000$ per year per BS) located in the Democratic Republic of Congo (DRC), mainly for O\&M purposes [5,20]. Additionally, it is noteworthy that there are also other common issues related to the deployment of diesel generators such as noise emission, oil spillage, theft risk, and limited shelf life [5,18,19,21-24].

\subsection{Renewable Energy Solutions}

Harvesting energy from renewable energy sources (i.e., solar and wind, in this case) to generate electricity for powering off-grid BSs is not a new feasible option. These solutions have been strong choices for powering BSs due to their abundant availability in a wide range of geographical locations around the world. Additionally, the components in solar- and wind-based systems are usually modular, which makes the design, expansion, and installation of these types of systems for the BS sites very practical and feasible [5]. However, due to the unpredictable and intermittent nature of wind and solar, the systems running on these sources typically need to be integrated with other means of renewable or non-renewable power supply and/or energy storage solutions in order to ensure the continuity of power supply in a BS site [25].

In a study conducted by the GSMA, which is a mobile trade organization, 320,100 renewable-based off-grid BS sites have already been rolled out in 2014 in regions like South Asia, Sub-Saharan Africa, Latin America, East Asia, the Pacific, and the Caribbean [26]. This number is expected to increase further in 2020 with about 389,800 sites [27]. Paudel et al. [28] highlighted that conducting a feasibility assessment is essential when designing renewable energy systems. This is to mitigate any poorly designed power supply system that is inefficient for powering a BS site. As is often the case, the renewable energy systems are usually over-sized, and this imposes high capital and O\&M costs to the telecom operators. In the same study, Paudel et al. [28] also claimed that $99.99 \%$ reliability can be achieved if solar and wind are deployed concurrently as a power supply solution and that the calculated, levelized cost of electricity supplied over the lifetime of the system and for an optimum design was reported to be just under $\$ 0.90$ per $\mathrm{kWh}$.

Another techno-economic study was conducted by Moghavvemi et al. [22] based on a HOMER (Hybrid Optimization of Multiple Energy Resources) analysis study for a standalone PV system supported by a battery energy storage system. The result showed that the optimal levelized cost of electricity for the power supply system can be as low as $\$ 0.46$ per $\mathrm{kWh}$ based on a PV contribution of more than $100 \%$, with excess energy after meeting the load demand and a battery autonomy of 2.6 days. Kusakana and Vermaak [5] discussed in their study that a PV system showed the lowest net present cost (NPC) which is $\$ 8,336$ per year compared to a wind system and a diesel system with costs of $\$ 11,420$ per year and $\$ 29,773$ per year, respectively, when used to power a BS site in the Democratic Republic 
of Congo. These NPC values were based on the total sum of capital, replacement, and O\&M costs while considering the salvage value of the power supply components.

Furthermore, with the existence of a new generation of small wind turbines that are lightweight and highly efficient, the future of wind-powered BSs looks more promising than before. This is due to the ability of the wind generators to supply power at lower wind speeds (e.g., $2 \mathrm{~m} / \mathrm{s}$ ) compared to the conventional models of wind generators (e.g., wind speeds at 3-6 m/s) [27,29]. Currently, the existing deployment of the new generation small wind turbines can be found in remote locations like the Middle East and Africa [27]. Based on a trial operation of Zephyr's Airdolphine PRO 48V DC wind turbine (generating $260 \mathrm{~W}$ at $6 \mathrm{~m} / \mathrm{s}$ ) at a BS site in Namibia, running a wind-battery system with a typical load of $1.2 \mathrm{~kW}$, the wind turbine produced an average daily energy production of $2.4 \mathrm{kWh}$ [30]. On best day of operation, the energy production went up to $10.1 \mathrm{kWh}$, making the trial operation a success for the wind turbine to complement the batteries since the application of the PV system is not relevant to that site. Moreover, using the same model of wind turbine, Vodacom tested the wind turbine at a low daily average of wind speeds, from $0.7-6.8 \mathrm{~m} / \mathrm{s}$, at a trial site in Tinana, South Africa [30]. The result showed that an average of $0.9 \mathrm{kWh}$ was achieved and, on the best day, $6 \mathrm{kWh}$ was produced.

\subsection{Hybrid Power Supply Systems}

\subsubsection{Why Hybridization?}

The hybrid power supply system is designed to utilize a combination of two or more power supply solutions (e.g., PVs and diesel generator) in order to achieve a more feasible, reliable, and environmentally friendly power supply arrangement. In particular, in terms of reliability, the deployment of a hybrid power supply system is able to reduce the intermittency of power supply and, accordingly, the need for a larger size of energy storage solution (e.g., batteries or hydrogen storage system) $[10,31,32]$. The selection of a hybrid power supply solution for a particular BS site is highly dependent on the availability of resources at the location [33]. Presently, the most common arrangements of hybrid power supply systems that are used to power BSs are PV-wind, PV-diesel-battery, PV-wind-diesel, and PV-fuel cell systems.

\subsubsection{Conventional Hybrid Power Supply Systems}

\section{PV-Wind Systems}

A hybrid PV-wind system generates energy to meet load demands through the good complementary effect of wind speed and solar radiation [34]. However, due to the stochastic nature of solar and wind energy, the hybrid PV-wind system (as shown in Figure 2) might need some form of energy storage (e.g., battery banks) that helps bridge the intermittency of the wind and solar energy sources and thus subsequently supplies power when the renewable energy sources are unable to meet the load demand [35]. 


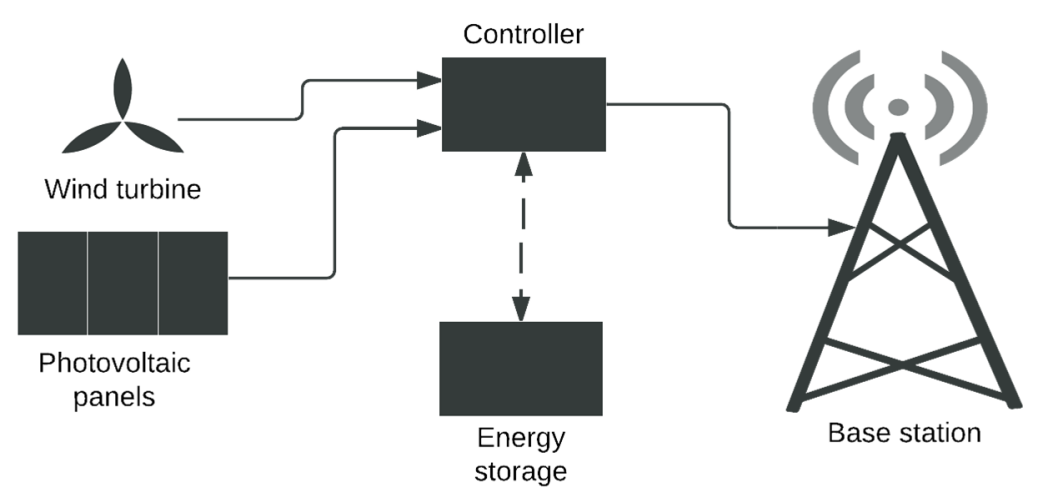

Figure 2. Typical configuration of a hybrid PV-wind system in a base station site.

Numerous literature has discussed the application of a hybrid PV-wind system for off-grid BSs. Hashimoto et al. [36] conducted a research study on a BS site in Yonaguni Island, Japan, where they proposed an optimal sizing of a hybrid PV-wind system and studied the possibility of service outages in three scenarios of battery capacity. The results showed that the system required a three-day backup battery in order to maintain zero hours of service outages. Furthermore, in a study conducted by Yu and Qian [37], the optimal sizing and control strategy of a hybrid PV-wind system was proposed where the dual-closed loop control method was used to track changes of wind energy in order to eliminate the wind change impacts on the hybrid PV-wind system.

Further optimization was made by Ribeiro et al. [38] to a hybrid PV-wind system used for powering an off-grid BS site where multi-input converters (comprised of a Cuk (current-voltage-current) and a buck converter (voltage-current-voltage)) are connected to the PV and wind generator, respectively. Two fault diagnosis techniques for the Cuk and the buck converter were suggested and analyzed using MATLAB/Simulink. As a result, the techniques allow an uninterruptible power supply for the BS by focusing on maximizing the usage of output power from the PVs and wind generator based on the utilization of the PV maximum power point tracking (MPPT) and port converter properties. Moreover, due to the ability to only use control variables to ensure a continuous power supply to the BS, no additional sensors or equipment (i.e., amplifiers) are needed to do so.

\section{PV-Diesel Systems}

The hybrid PV-diesel system (typically with battery energy storage) is a comprehensive power supply system that works based on the complementary roles of the key components of the system; for instance, the high capital cost of the PV is compensated by the low capital cost of the diesel generator while the high O\&M costs of diesel are compensated by the low O\&M costs of PV. In most cases, the energy generated by the diesel generators is fairly available during the absence or shortage of the PV's power output [39]. Additionally, while the existence of diesel as a back-up power supply increases the reliability of the hybrid PV-diesel systems, the overall capital and O\&M costs can be further decreased by employing a much smaller size of PVs and batteries [39].

Husain and Sharma [40] conducted a HOMER study for a hybrid PV-diesel system used to power a substation in Nepal and found that based on an NPC economic analysis approach of an optimized hybrid PV-diesel system, the cost of electricity supplied by the system was found to be $\$ 0.50 / \mathrm{kWh}$. When compared with a diesel-only system, the cost of electricity supplied by the system was found to 
be $\$ 0.70 / \mathrm{kWh}$. Additionally, by adding an inverter to the hybrid PV-diesel system, there was an improvement in energy delivery from the PV without the need to discharge the battery as long as there is enough solar radiation onsite [40]. This can help prolong the battery's lifetime and prevent the intermittency of the diesel generator, making the combination of the hybrid PV-diesel to be feasible and practical when compared to a diesel-only system [40].

In another HOMER study by Moghavvemi et al. [22], an optimized hybrid PV-diesel system proposed to power an off-grid FM (frequency modulation) transmitter located in Kuantan, Malaysia, yielded the lowest cost of electricity, at $\$ 0.26 / \mathrm{kWh}$, when compared to a diesel-only system and a PV-only system, at $\$ 0.36 / \mathrm{kWh}$ and $\$ 0.46 / \mathrm{kWh}$, respectively. This optimization was done by considering the two key parameters of autonomy days and PV contribution, suggesting half a day of autonomous operation with a PV contribution of $110 \%$ (meaning there was a $100 \%$ PV contribution and an additional $10 \%$ of excess power from the PV) in order to achieve the lowest electricity cost of $\$ 0.26 / \mathrm{kWh}$ [22].

It is important to note that factors such as high emissions from diesel usage, possible future increased cost of diesel prices, and unreliability suggested by the service outages (e.g., due to poor supply of fuel or fuel theft) are some of the limitations that prevent the hybrid PV-diesel system to be favorably deployed for powering off-grid BS sites [41-43]. Figure 3 shows a typical set-up of the hybrid PV-diesel systems where the power is primarily supplied by the PV system and the diesel generator acts as a complementary power supply system to overcome the intermittency of solar energy. During periods when the PVs are able to generate excess energy, the energy storage is used to store the excess energy as a short-term energy storage option. Nevertheless, due to the non-existence of reliable long-term energy storage, the PV-diesel system is not reliable enough to power the off-grid BS sites with a seasonal type of loading [43].

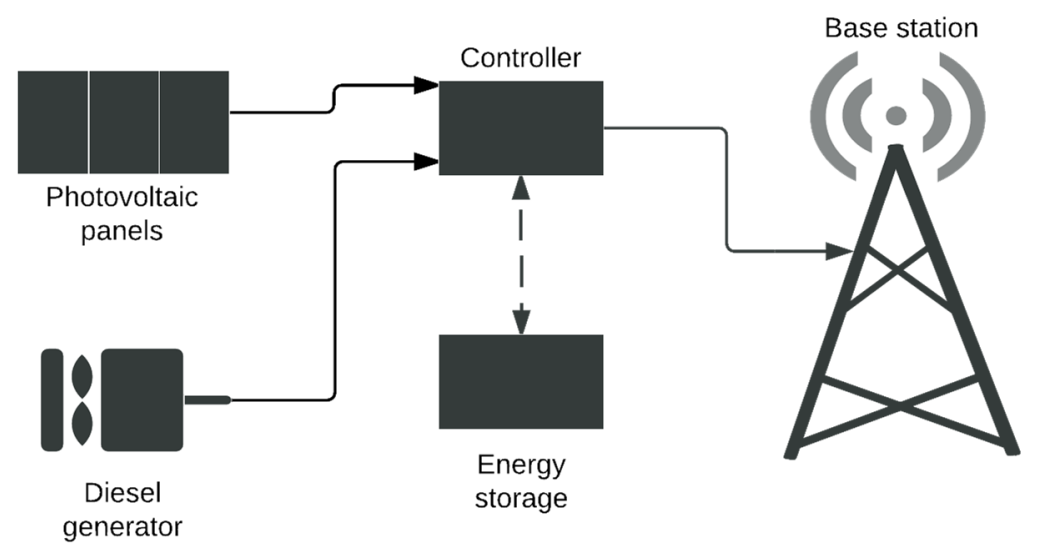

Figure 3. Typical configuration of a hybrid PV-diesel system in a base station site.

\section{PV-Wind-Diesel Systems}

In hybrid PV-wind-diesel systems, electrical energy is supplied primarily from solar and wind energy while diesel is used as a secondary or backup power supply when the PVs and wind generators are unable to produce enough power for the off-grid BS [21,44]. Figure 4 shows the typical configuration of a hybrid PV-wind-diesel system for powering a BS site. The study conducted by Bitterlin [45] suggests that the hybrid PV-wind-diesel systems are ideal for powering large-sized BSs of $4 \mathrm{~kW}$ or more. A similar study has been conducted by Goel and Ali [46] based on a hybrid PV-wind-diesel system that is 
located at the island village of Barakolikhola in Odisha, India. The study showed that desirable outputs such as low emissions, low operating costs, low net present cost (NPC), and levelized cost can be achieved when deploying a hybrid PV-wind-diesel system to the BS site rather than a diesel-only power supply system. They also showed that the deployment of such a hybrid system is more viable, both technically and economically, when used for larger load demands.

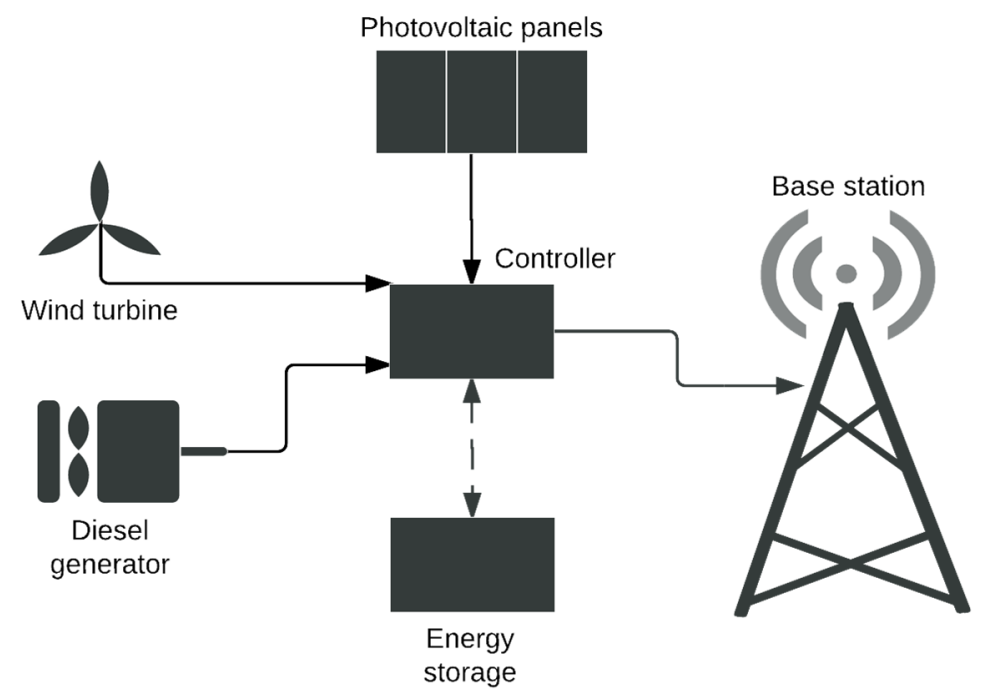

Figure 4. Typical configuration of a hybrid PV-wind-diesel system in a base station site.

Sharma et al. [47] studied the optimization of a hybrid PV-wind-diesel system based on a HOMER analysis of an off-grid BS site located in Imaliya Bhanpur, India. The results showed that the NPC of the hybrid PV-wind-diesel system is $10 \%$ and $15 \%$ lower than the hybrid PV-diesel and wind-diesel systems, respectively. In addition, the cost of electricity per $\mathrm{kWh}$ for the three hybrid systems (i.e., PV-wind-diesel, wind-diesel, and PV-diesel systems) was found to be $\$ 0.70 / \mathrm{kWh}, \$ 0.77 / \mathrm{kWh}$, and $\$ 0.76 / \mathrm{kWh}$, respectively.

Another HOMER study conducted by Olatomiwa et al. [48] suggests that the hybrid PV-wind-diesel systems are used to replace diesel generators that were previously deployed for off-grid BS sites in Nigeria. This is because the hybrid PV-wind-diesel system yield a lower cost of electricity at $\$ 0.45 / \mathrm{kWh}$ compared to hybrid PV-diesel and diesel-battery systems, where both suggested a unit of electricity of $\$ 0.66 / \mathrm{kWh}$ in this case study. Moreover, the renewable fraction of the hybrid PV-wind-diesel system was found to be higher (i.e., above 82\%) than just that for the hybrid PV-diesel system (i.e., at 19\%), making the proposed hybrid power supply system to be feasible and environmentally friendly compared to other hybrid power supply configurations.

\section{PV-Fuel Cell Systems}

A hybrid PV-fuel cell system is a sustainable solution (if hydrogen is produced and supplied sustainably) that can be used to power an off-grid BS site based on the attractive features of the PV and fuel cell technologies, such as high efficiency, modularity, and fuel flexibility [49]. Figure 5 shows the typical configuration of a hybrid PV-fuel cell system used for powering a BS site. Generally, the fuel cell system is used to back up the power supply system by covering the intermittency of the PV system, 
particularly when the energy storage of the system is unable to supply enough electricity to meet the BS demand. The preferred fuel cell option for this purpose is Proton Exchange Membrane Fuel Cell (PEMFC) due to its low operating temperature (e.g., 60-100 ${ }^{\circ} \mathrm{C}$ ), rapid start-up, and rapid response to variable loads [50]. The PEMFCs can run on pure hydrogen that can be supplied to the site or generated onsite, for instance, through water electrolysis or reforming methanol and natural gas [51].

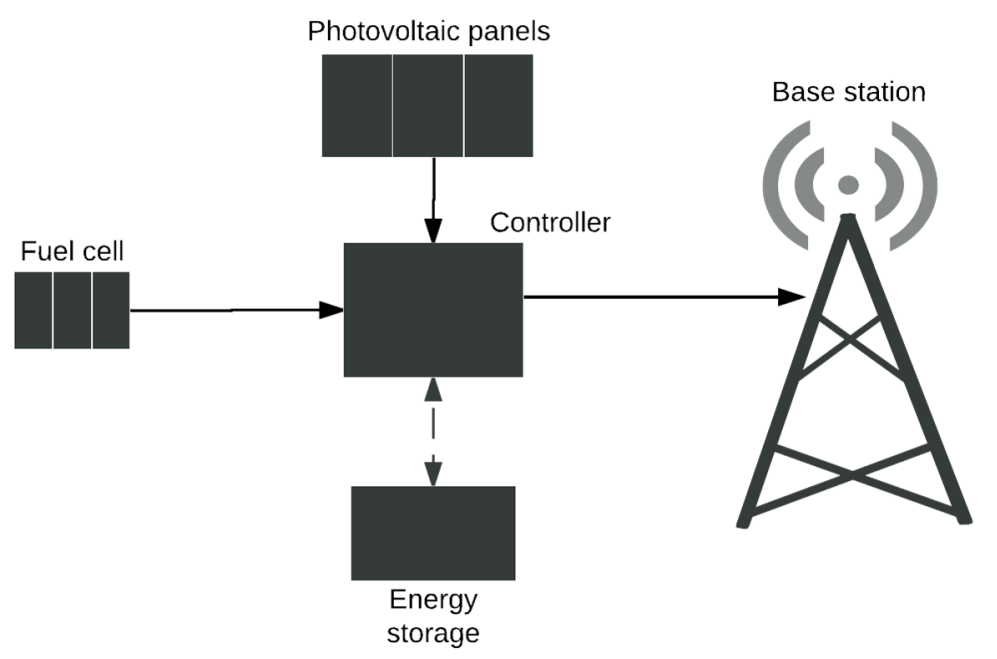

Figure 5. Typical configuration of a PV-fuel cell system in a base station site.

In a study conducted by Jiang [49], an unattended test operation of a hybrid PV-fuel cell system was conducted for a remote radio-telephone repeater station. The results showed that the power supply system operated without any failure for $3239 \mathrm{~h}$ (or over 229 days in service) and completed 177 start-stop cycles and kept the batteries at an average of a $76 \%$ state of charge (SOC). However, the test operation failed not long after that due to overheating from the fuel cell as the ambient temperature increased and the cooling system was left in an idle state in order to reduce energy consumption of the BS. This highlights the importance of an effective thermal management system for such power supply arrangements; this will be further discussed in section 3.4 of "Thermal Management of Base Stations".

Another case study of a remote radio-telephone repeater station was conducted by Lehman et al. [52] with the aim of deploying a feasible power supply system for the repeater station. They found that a PV-only system was not feasible as it required a large number of PVs, whereby the diesel-only system required huge amounts of diesel to run the repeater station. Because of that, a hybrid PV-fuel cell system was proposed and the result showed that the PEMFC performed flawlessly as a backup power supply to the hybrid system at 400 to $800 \mathrm{~h}$ of operating hours per year. Moreover, a temperature switch was introduced in order to overcome the overheating issue that was previously experienced by the hybrid PV-fuel cell system.

A study by Rekioua et al. [33] added that a Power Management Unit (PMU) managed to successfully improve the power coordination between the PVs and the fuel cell. By adding the PMU to the power supply system, the number of PVs needed in addition to the capital cost of the hybrid PV-fuel cell system was further reduced. However, drawbacks like slow dynamics in the fuel cell system and the high capital cost of the fuel cell somewhat inhibited the deployment of the proposed hybrid PV-fuel cell system for the remote telecommunication applications that the system was designed for. 


\subsection{Energy Storage}

\subsubsection{Overview}

Energy storage is an important element in a hybrid power supply system, simply to fill the gaps of supply when utilizing intermittent renewables (e.g., during the absence of sufficient wind and/or PV power output or during unexpected or irregular load consumption) [53]. In addition, the energy storage system stores surplus energy during the periods when the energy generation is more than the demand and releases this energy when the load demand is more than the energy generation [54]. The energy storage also acts as an energy buffer by compensating the imbalances found between the energy generation and the demand and it improves the system's reliability so that any power interruption within the telecommunication networks can be mitigated [54].

As discussed by Koutitas and Demestichas [54] and Yekini Suberu et al. [55] in their literature, common types of energy storage systems can be classified into four main categories which are mechanical (i.e., flywheel, pumped hydro system (PHS), and compressed air storage systems), electrical (i.e., super-capacitors, capacitors, and superconducting magnetic energy storage (SMES)), thermal (i.e., low and high temperature energy storage systems), and chemical (i.e., electrochemical, thermochemical, and chemical storage devices).

Thus, in this paper, the focus will only be on the electrochemical type of energy storage systems, including batteries, hydrogen systems, and hybrid energy storage systems (e.g., batteries and hydrogen energy storage systems) that are widely used with power supply systems for powering off-grid BSs.

\subsubsection{Electrochemical Energy Storage Solutions}

\section{Batteries}

A battery is a type of electrochemical energy storage device that can convert stored chemical energy into electrical energy and vice versa during its recharge process [54]. Typically, the battery can be classified into two categories, which are low-temperature internal storage and high-temperature external storage. The low-temperature internal storage is an energy storage system that can optimally perform at room temperature (e.g., $\left.25^{\circ} \mathrm{C}\right)$ and some examples of this are lead acid $\left(\mathrm{PbO}_{2}\right)$, nickel cadmium $(\mathrm{NiCd})$, lithium ion (Li-on), sodium metal-halide, and nickel metal hydride (NiMH) batteries [55]. Using these batteries at extreme cold or hot conditions can negatively affect their charging and discharging performance [56-60]. For high-temperature external storage, its chemical storage system and electrical conversion unit are separated but somehow linked during charging or discharging processes in order to allow the electrochemical reaction exchanges to happen [55]. Some examples for this type of battery are redox-flow and primary batteries with external regeneration.

According to Divya and Ostergaard [61], the lead-acid batteries incorporate the most mature technology and have been used for most power supply system applications. However, the Li-ion and $\mathrm{NiCd}$ batteries seem to demonstrate the latest development in battery technology due to their smaller size, low weight, and ability to offer a high energy density and storage efficiency of close to $100 \%$ [60,62-65]. Despite the advantages possessed by the Li-ion and NiCd, major drawbacks of these 
types of batteries are their high cost and the unfavorable effect of deep discharging across the battery's overall lifetime [60,62-65].

For off-grid BS applications, the sizing of the battery is very much dependent on the following system requirements: voltage and current; charge and discharge rates and duration; operating temperature during charge and discharge; life in number of charge and discharge cycles; as well as cost, size, and weight constraints [66]. As studied by Rijssenbeek et al. [18], the deployment of highly durable batteries like sodium-metal halide are useful in supporting diesel systems. Additionally, Rijssenbeek et al. [18] also found that a fuel savings of up to $50 \%$ and a reduction of up to $70 \%$ in the overall running time of the diesel generator can be achieved by using such batteries.

In a study conducted by Merei et al. [67], the economics of PV-wind-diesel systems for off-grid BSs with three different battery technologies (i.e., lead-acid, vanadium-redox-flow, and Li-ion) were studied. The results showed that by adopting batteries in the power supply systems, the energy costs became $50 \%$ cheaper compared to the energy costs generated by the diesel generator alone. Additionally, when comparing the economics of the hybrid PV-wind-diesel systems with the three types of battery technologies, vanadium-redox-flow systems yielded the cheapest technology $(\$ 0.73 / \mathrm{kWh})$ compared with lead-acid $(\$ 0.77 / \mathrm{kWh})$ and Li-ion batteries $(\$ 0.81 / \mathrm{kWh})$ [67]. Merei et al. [67] also discussed that without the deployment of batteries in a hybrid renewable-based system (e.g., PV-wind-battery system), the energy cost was found to be too expensive, about $\$ 1.52 / \mathrm{kWh}$.

\section{Hydrogen-Based Energy Storage Systems}

The use of intermittent renewable energy as a power supply source has led to the utilization of hydrogen as a means of energy storage, both for long-term and short-term solutions as discussed in various studies of Bak et al. [68], Ghosh et al. [69], Agbossou et al. [70], Kaviani et al. [71], and Bahman and Andrews [50]. By linking the fuel cells and an electrolyzer together, the combination can form a fuel accumulator-like device that can store and generate electricity through electrical processes [55,72]. For a hydrogen-based energy storage system that only requires hydrogen to "fuel" the system, the deployment of such a system would generate no carbon-based emissions (e.g., $\mathrm{CO}_{2}$ ). Moreover, having the flexibility to store energy in the form of hydrogen, either in gas or liquid phase, or by using metal hydride allows broader prospects to deploy this type of energy storage system for various types of applications (e.g., telecommunication, remote power supply, residential, aerospace, etc.) [73-76].

Vosen and Keller [73] discussed in their literature that the hydrogen-based energy storage systems can store energy cheaper than conventional batteries, making this option feasible when coupling with renewable energy systems or hybrid power supply systems. However, the high capital costs associated with the hydrogen-based energy storage system somewhat offset the low energy storing cost when hydrogen balance is achieved, and this issue hinders the future development of the system $[73,77,78]$.

In the context of off-grid BS applications, the hydrogen-based energy storage systems have received increasing attention for providing a more environmentally friendly telecommunication network as well as acting as a major foundation to support the future hydrogen economy [55]. The common type of fuel cells that can be found in the off-grid BS application is PEM fuel cells due to their low operating temperature (i.e., easy to start-up), quick response to changing loads, and durability. The PEM fuel cells also possess other advantages compared to other types of fuel cells, such as simplicity in design, robust 
yield, low emissions, and low weight with high power density, as well as the ability to use atmospheric air for energy generation [55]. Figure 6 shows an example of the application of a hydrogen-based energy storage system in a hybrid PV-hydrogen system for powering off-grid BSs [79]. By integrating the PVs with the use of the hydrogen energy storage system, an environmentally friendly power supply can be generated which further reduces the O\&M costs of the power supply system [80,81].

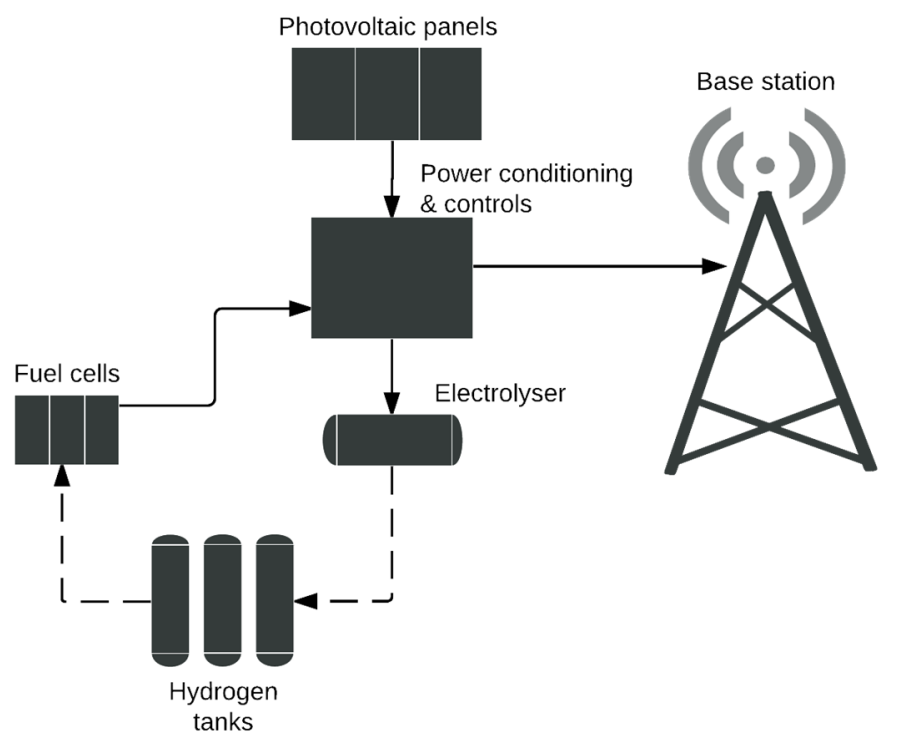

Figure 6. An example of a hydrogen-based energy storage system application present in a PV-hydrogen system for an off-grid base station.

In a study conducted by Agbossou et al. [82], the performance of a hybrid PV-wind-hydrogen system is studied comprehensively for a telecommunication station. The results of the analysis showed that the excess power from wind is used to generate hydrogen for later usage when the renewables are unavailable. Furthermore, in the same study, the efficiency of PEM fuel cells was found to be better than $42 \%$ when linked to a DC/DC converter, and this helps to stabilize the power supply to the station.

Dokkar et al. [83] studied that for a BS site in Algeria running a hybrid PV-hydrogen system, due to the absence of short-term energy storage (e.g., batteries), the number of PVs was found to be relatively high (i.e., 80 modules of $300 \mathrm{~W}$ ), which led to the high capital cost of the system. Nevertheless, the integration of the PV system and hydrogen-based energy storage system (i.e., fuel cell and electrolyzer) has managed to overcome logistical problems (e.g., during the case of deploying diesel generators or batteries).

\section{Hybrid Energy Storage Systems}

The development of renewable-based standalone power supply systems is hindered partly due to the lack of feasible energy storage solutions. In most cases, the seasonal variation of renewable energy sources is the main factor that leads to the deployment of long-term energy storage solutions, while the intermittent nature of the renewables permits the deployment of short-term energy storage solutions [39,84,85]. As discussed by Vosen and Keller [73], conventional battery storage is energy efficient with round-trip efficiencies of $80 \%-90 \%$ (when used as short-term energy storage), but the cost of storing electrical energy in the batteries can be considerably more expensive than hydrogen-based 
storage. This higher cost is mainly linked to the maintenance cost of battery systems, particularly in remote sites with no easy access [50]. This is while the hydrogen-based storage systems are usually of higher capital costs compared to batteries. Hence, by hybridizing both types of solutions (i.e., long-term and short-term energy storage) through the deployment of multiple energy storage arrangements, they can complement each other through their performances.

In hybrid storage systems in which both batteries and hydrogen systems are used, the overall cost of the system, depending on the nature of the applications, can be cheaper [41,73] or more expensive [39,50] than using either of the systems alone. Based on a techno-economic study by Bezmalinovic et al. [39], the levelized cost of electricity with and without a hybrid energy storage system (i.e., PV-hydrogenbattery and PV-battery systems, respectively) was found to be $\$ 0.70 / \mathrm{kWh}$ and $\$ 0.72 / \mathrm{kWh}$, respectively. However, in an experimental study made by Petrollese et al. [86], by expanding the hydrogen-based storage capacity compared to adding batteries in renewable energy power supply systems, a savings of about $10 \%$ was achieved in annual O\&M costs and a $6 \%$ decrease of energy losses was expected. However, either way, hybridization of the storage system can enhance the reliability of the system that is essential in BS sites in which 100\% reliability and uninterrupted operation are required [41,50,87-90]. Figure 7 shows the schematic diagram of a hybrid energy storage system used in a typical BS site. The mechanism of the hybrid energy storage system is similar to that of a hybrid PV-fuel cell system. However, the ability to generate hydrogen onsite from the excess energy produced by the PVs is a great option for BSs with seasonal variant loading.

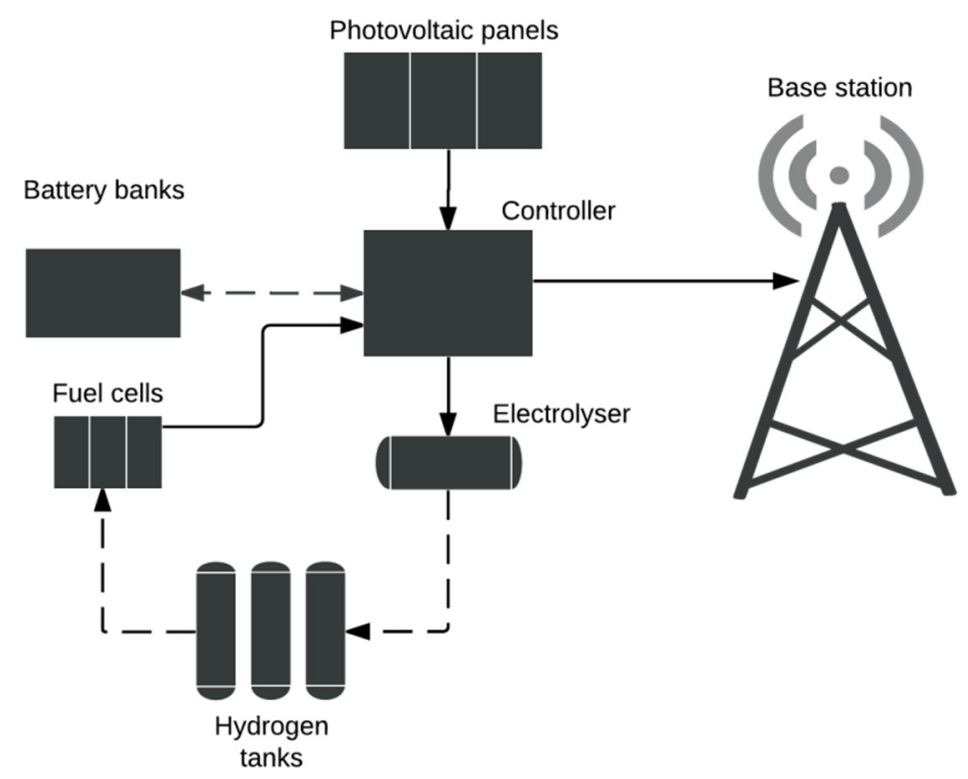

Figure 7. An example of a hybrid energy storage system (i.e., batteries and hydrogen system) application present in a PV-hydrogen/battery system for off-grid base stations.

\section{Key Aspects of Power Supply System Design for Off-Grid Base Stations}

\subsection{Overview}

A comprehensive load profile study is essential in order to achieve a well-designed power supply system. In the case of off-grid BS electrification, the study of the load profile allows the possibility to 
achieve a balance between the energy demand and supply for the purpose of obtaining an optimum and cost-effective power supply system [35]. Generally, the energy consumption of an off-grid BS site varies throughout the day concurrently with the energy production by renewable sources [91]. Similarly, the variant mode of operations of the BS (e.g., during low traffic or peak traffic mode) also has an impact on the energy consumption pattern of the BS [91,92]. For the case of mobile and wireless telecommunication networks, the end users are connected to the BSs through a wireless channel, where each of the BSs is connected to other networks via a wireless point-to-point link or wired-based connection [92,93]. At present, several wireless access technologies have existed, and the latest one is LTE (Long-Term Evolution), similarly known as 4G technology, and 5G technology will be deployed soon [93].

As discussed in numerous literature, different metrics have been defined to date for measuring energy efficiency and power consumption at various levels (i.e., component level, access node level, and network level) wherein the energy efficiency represents the ratio of attained utility (e.g., coverage area, output power, bits transmitted, etc.) to the power consumption and vice versa for the case of the power consumption metric [94]. To improve the energy efficiency of BSs, strategies such as reduction of the BS energy consumption through sleep or idle mode [3,9,92,93,95]; device-to-device (D2D) communication [96]; utilization of high efficient technologies (i.e., improved power amplifiers, high-efficient air conditioning systems, cognitive radio technology, as well as fixed and cooperative relays) $[3,15,16,92,95,97]$; critical energy management [98,99]; proper sizing and optimization of the power supply system [10,13]; site sharing and heterogeneous cellular networks $[3,92,99,100]$; as well as cell shaping and an increased number of carrier frequencies [94,95] can be deployed to achieve the energy efficiency of BSs at various levels.

Typically, an off-grid BS site needs to supply an average of 1-3 kW throughout the day in order to power all the equipment and sections of the BS [101]. Lorincz et al. [99] discussed that the energy consumption of the BS can be divided into two sectors: first, the radio frequency equipment which comprises power amplifiers and transceivers and, second, the support system which comprises AC/DC power conversion modules, heating and/or air conditioning elements, analogue and digital signal processors, battery backup, etc. [99]. Figure 8 shows an example of the breakdown of power requirements for different modules in a typical high-powered off-grid BS site (of about $2 \mathrm{~kW}$ ) where the radio frequency, heating and/or cooling systems, and power supply are the top three main energy-intensive elements of the site with power requirements of $1000 \mathrm{~W}, 500 \mathrm{~W}$, and $150 \mathrm{~W}$, respectively. To accurately analyze the load of a BS site, the power model approach can be used as suggested by Auer et al. in [12] and [102], and the relation between radio frequency power transmission and power supply consumption is established accordingly. Additionally, the total energy consumption can be expressed as Equation (1) below:

$$
P_{\text {TOTAL }}=n_{S C}\left[n_{T X} P_{A m p}+P_{\text {Trans }}+P_{\text {Proc }}+P_{D C / D C}+P_{G e n}\right]+P_{\text {Cool } / \text { Heat }}
$$

where $P_{\text {TOTAL }}$ is the total energy consumption of the $\mathrm{BS}, n_{S C}$ is the number of sectors, $n_{T X}$ is the antenna number of the BS, $P_{A m p}$ is the energy consumed by the amplifier, $P_{\text {Trans }}$ is the energy consumed by the transceiver, $P_{P r o c}$ is the energy consumed by the digital processing equipment (i.e., radio frequency and baseband), $P_{D C / D C}$ is the energy consumed by the converter, $P_{G e n}$ is the energy consumed by power supply components, and $P_{\text {Cool/Heat }}$ is the energy consumed by the cooling/heating system. 


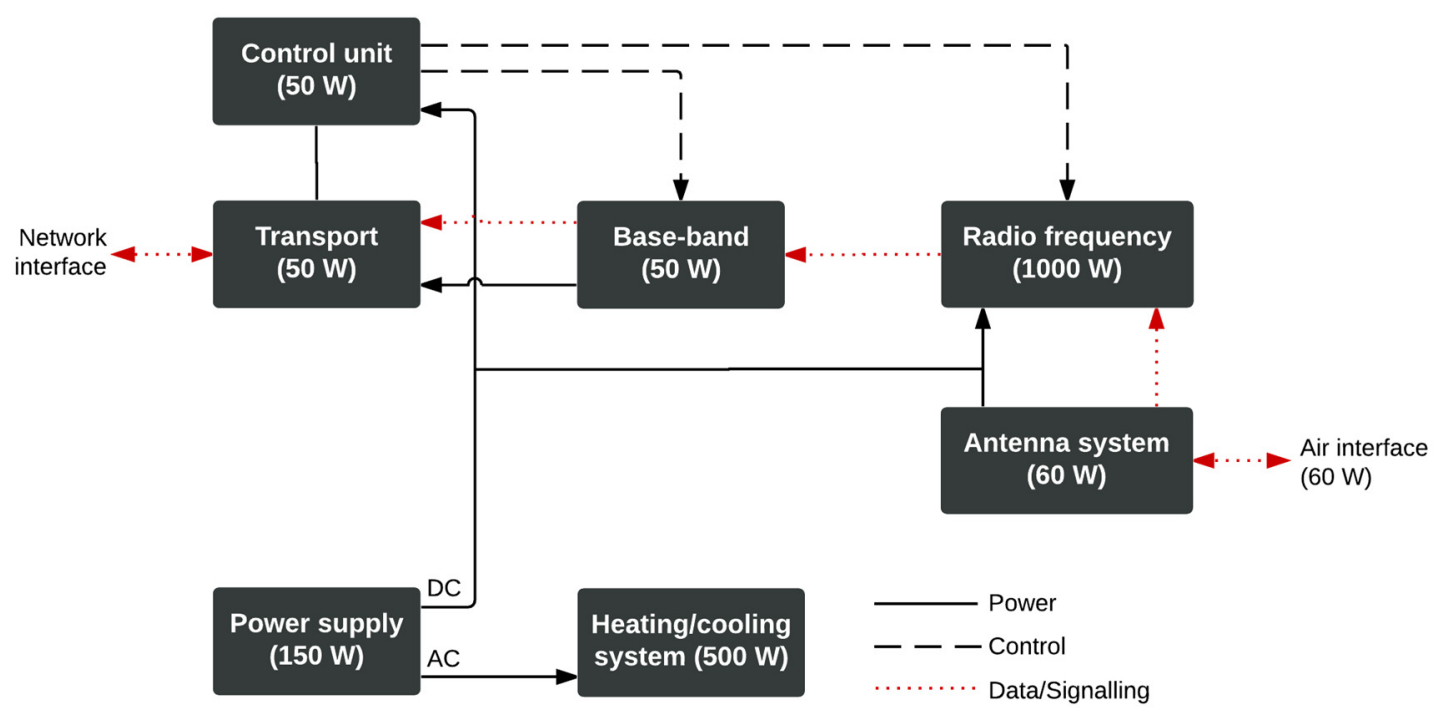

Figure 8. Power requirements of different modules in a typical base station site [91].

\subsection{Pre-Feasibility Study}

The first step in designing an optimal power supply system for an off-grid BS site can be done through a comprehensive pre-feasibility study where the performance of the power supply system is dependent on the environmental condition of the BS site. Hence, the need to conduct a specific site analysis is critical in order to investigate the potential associated cost, the component size needed, and the overall economics of the proposed power supply system [77]. For a power supply solution that uses renewable energy, meteorological data are important in order to properly size and optimize the power supply system for the off-grid BS. Commonly, the meteorological data can be obtained based on historical data of the location; however, for sites that do not have complete records, experimental measurements or high accuracy estimation is being used in order to predict the data [103].

The two likely approaches for estimating the meteorological data are the chronological approach and the stochastic approach [103]. In the chronological approach, the first step is to determine the wind or solar profile of the site. This can be done by obtaining information from the Internet or producing the wind or solar profile through a calculation-based approach. Secondly, for any incomplete data sets, the information can be synthesized by introducing some randomness when synthesizing the data sets. This can be done by using statistical algorithms (i.e., the Graham algorithm or Graham model, which is a method to generate synthetic hourly solar radiation that is commonly used in solar simulation design work [104]) that can be found in the HOMER [103]. Although the chronological approach is quite straightforward, the downside of the approach is that it cannot represent an accurate future climate condition due to the nature of the climate that is varying from year to year [103]. Therefore, when that is the case, a more complex approach such as the stochastic approach shall be used where the availability of the energy resource and load demand are considered as random variables. 


\subsection{System Sizing and Optimization}

Proper sizing and optimization of the power supply systems used for powering off-grid BSs can have positive impacts toward the systems' reliability, as well as toward the costs associated with their installation, operation, and maintenance [105]. Various studies have been carried out by other researchers to design for the sizing and optimization of the standalone power supply systems, and these the studies mainly focused on suitable hybrid components and configurations of the system at the lowest possible cost while meeting the load demands of the BSs at all conditions [106].

Generally, the sizing and the design of the power supply systems are dependent on the location and environmental conditions of the site, where the availability of the site's weather data determines the appropriate sizing method that shall be used to carry out the design and sizing of the systems [107]. Using the existence of weather data, conventional sizing approaches are applied based on the concept of energy balance and the reliability of supply [107]. For instance, to size a PV system, long-term meteorological data is needed. As discussed by Marsan et al. [92], sizing of the PV system can be done by looking at the month with the minimum energy production. The value of the nominal peak power of the PV system is then matched with the energy requirement of the BS on average [92]. Additionally, the daily average load demand together with the daily average available energy from the sun are balanced in order to obtained the number of PV arrays required by the system [107]. Being the simplest technique in sizing the power supply components, the energy balance takes into consideration the path losses and efficiencies of the energy sources (i.e., renewable energy), converters, and controllers, while the reliability of the supply approach estimates the loss of load probability by calculating the ratio of all energy deficits to the load demand at a certain period of time [34,108,109]. Likewise, other similar concepts for the reliability of the supply approach are loss of power probability (LOPP), loss of power supply probability (LPSP), and load coverage rate (LCR) [107].

However, in most cases (i.e., particularly in off-grid BSs), the weather data is often absent and more complex techniques (i.e., Artificial Intelligence (AI)) are needed [107]. This is when the AI generates results based on the prediction or classification of input data (with an appropriate degree of error) and presents it as new sets of data patterns of previous examples and models [107]. The examples of the AI techniques that are commonly used for the design and sizing of the power supply systems are the Artificial Neural Network (ANN) [110,111], Fuzzy Logic [108,112], Genetic Algorithms (GA) [43,66,101,105,113], wavelet transforms [114], and hybrid methods with multi-objectives (combinations of two or more AI techniques) [115,116]. An example of PV system sizing using an AI technique of the ANN is where the longitude and latitude of the BS site location are considered as the inputs to the ANN. The outputs are then estimated based on the ANN model for sizing of the PV system. As a result, the ANN technique is able to determine the number of PV arrays and the size of the batteries with a relative error of less than $6 \%$ [117].

Often after the design and sizing of the power supply systems, optimization of the system is needed in order to further minimize the system cost and at the same time increase the reliability of the system [107]. This can be done by assessing appropriate performance indicators in order to measure the level of feasibility and reliability of the power supply components [115]. Some of the key performance indicators used when carrying out the optimization of the power supply systems are: levelized cost of energy (LCE), which is an economic assessment of the energy generated by the power supply system 
based on the calculated ratio of the total annualized cost of the system to the annual electricity supplied by the system $[118,119]$; the battery's state of charge (SOC), which measures the energy storage capacity of the power supply system $[43,120]$; the level of autonomy that assess the reliability of the power supply system by calculating the fraction of time in which the BS demands are met [121-123]; the expected energy not supplied (EENS), which measures the expected energy that cannot be supplied by the power supply system [124]; the net present value (NPV), which measures the economics of the power supply system by calculating the NPV of the system based on the addition of present values of incomes and the subtraction of the discounted present costs throughout the system's lifetime period [125]; and lastly, the annualized cost of system (ACS), which is an economic assessment of the power supply system based on the calculation of the total annualized capital cost, the annualized replacement cost, and the annualized maintenance cost [126].

The common methods that are used to optimize the power supply systems include Genetic Algorithm (GA) [66,67,101,105,108,109,116,127-129], Particle Swarm Optimization (PSO) [71,78,128,130,131], Simulated Annealing (SA) [132,133], Honey Bee Mating Optimization (HBMO) [134,135], Neural Networks (NN) [111,114,136,137], Evolutionary Algorithm (EA) [66,116,134,138], and Simplex Algorithm [128,134,139,140]. In the context of remote telecommunication applications, Okundamiya et al. [127] applied the GA approach to optimize a hybrid PV-wind-battery system for a BS site. The GA uses three operators (i.e., selection, crossover, and mutation) and the selection process begins by evaluating the initial system design (known as chromosome, chosen or set by default) to preliminarily determine a reliable power supply to meet the load demand. If the evaluation of the qualified chromosome yields a lower cost of energy than the previously obtained lowest cost of energy value (based on previous iteration), the chromosome of the system configuration is considered to be the optimal solution. The iteration of the selection process is then repeated again until the optimal solution is obtained before moving on to the crossover and mutation operations [127].

As discussed by Erdinc and Uzunoglu [128], another two promising techniques, Ant Colony Algorithm (ACO) and Artificial Immune System Algorithm (AIS), are increasingly favorable to be used for power supply optimization. According to Dorigo and Stützle [141], the ACO is a technique that was inspired based on the observation of ant colonies where the larger the colony, the larger the probability for the ants to use the same food path in the future based on the pheromone level that the ants leave along the food path. The same theory is adopted when sizing the power supply systems where the energy resources act as the ant colonies and their sizing configurations act as the coordinates of the food path. Hence, when the ants search for the food, the ACO will search for the optimal configuration of the power supply systems based on the iterative process of the search space within the assigned parameters [128].

\subsection{Thermal Management of Base Stations}

\subsubsection{Overview}

The thermal management of BSs is another important key aspect when designing an optimized power supply system for the BS. In the context of off-grid BS applications, most of the BS sites are located in remote locations and typically experience moderate to extreme climate conditions (i.e., extreme cold 
and/or extreme hot conditions in mountainous and desert areas, respectively), especially during winter and summer periods. As is often the case, the extreme low (subfreezing) and/or high temperature operations can lead to performance degradation of power supply components (i.e., PEM fuel cells and batteries) due to cold-start, premature capacity loss, overheating, etc. [65,142,143]. For those reasons, the thermal management of BS components (i.e., BS shelter/cabinets, BS electronic equipment, and power supply components) is important as they act as a significant measure toward the energy efficiency of the BSs [144-146]. This is done by regulating the ambient temperature of the BS components to desirable levels in order to maintain the performance of the BS components [147-153].

Over the years, common approaches for BSs' thermal management have been limited to only BS shelter/cabinets and BS electronic equipment. As is often the case, during sizing and optimization of power supply systems, the thermal loads are usually ignored or assumed to be $30 \%-50 \%$ of the total BS load and they are typically studied as one-dimensional [154,155]. Earlier studies showed that the thermal management for BSs is done using heat recovery systems [156]: thermal management using heat pipes and thermal electrical elements based on a two-stage heating and cooling process [157]; passive thermal management using heat pipes for cooling and a power amplifier for heating [158]; thermal management using Closed Cycled Vapor Turbo generators (CCVTs) [159]; a heating and cooling system of BS enclosures and batteries using vortex tubes [160]; thermal management using free-cooling and phase change materials (PCMs) [161]; a thermal energy storage transfer system using PCM, heat pipes, and a condenser [162]; and thermal management using a two-phase thermo-syphon loop [163]. However, the studies were limited to only heating and cooling of BS shelter/cabinets, thermally removed heat from BS electronic equipment, and heating of the batteries.

\subsubsection{Cooling}

Cooling of BS components is critical in order to maintain an optimum ambient temperature of the BS shelter/cabinets as well as the operating temperatures of the BS electronic equipment and power supply components. Tu et al. [154] as well as Darwiche and Shaik [155] reported that the cooling system usually consumed about $30 \%-50 \%$ of the total BS electricity in order to maintain the BS at its optimum level. However, it is noteworthy that the given range may vary at moderate and extreme climate conditions. Hence, effective cooling is needed in order to maintain the performance and reliability of the BS components.

As the size of BSs continues to increase due to growing demand in the mobile telecommunication network, so does the power consumption and the heat dissipation level of the BS electronic equipment [148]. Settou and Benmhidi [164] discussed that the heat loss of BS electronic equipment varies between 0.5-10 kW, depending on the size and the type of equipment. Zhang et al. [165] suggested that the heat loss from the BS electronic equipment was found to be $4.35 \mathrm{~kW}$, while the inner heat source of the BS shelter (with a built-up area of $21.72 \mathrm{~m}^{2}$ ) was about $200 \mathrm{~W} / \mathrm{m}^{2}$. Meanwhile, in another study by Gianolia et al. [161], a Green Shelter with a built-up area of about $6 \mathrm{~m}^{2}$ was used to measure the heat dissipation of BS electronic equipment together with a power supply system deploying fuel cells as a backup power supply. The result was found to be $2 \mathrm{~kW}$ of the internal heat source and active cooling with low energy consumption was used for this experimental study.

Effective energy saving measures such as employing highly efficient air conditioning systems [150,152,153], proper design of the building envelope [154,165,166], indoor airflow 
optimization [167], as well as the reduction of cooling loads through energy efficient BS electronic equipment and energy management monitoring [168] are some of the solutions that have received more attention in recent years. A study of BS cooling using a two-phase loop-type thermo-siphon system that was integrated inside the wall had been introduced by Nakao et al. [166]. The concept of the integrated wall was to obtain a higher heat transfer coefficient compared to an ordinary wall, which potentially leads to an estimated savings of $20 \%$ of the cooling energy needed by the BS.

Shahirinia et al. [66] studied that by increasing the tolerance of the BS electronic equipment by $4{ }^{\circ} \mathrm{C}$, from $21^{\circ} \mathrm{C}$ to $25^{\circ} \mathrm{C}$, this approach can contribute to about $10 \%$ of cooling energy reduction. Choi et al. [152] studied a new ventilation cooling technology (VCT) for a BS site and found that the VCT can cool the BS shelter/cabinets by extracting outdoor cold air through a fan that is controlled by an environmental control when the humidity and temperature of the outdoor air meets the equipment requirement. This approach remarkably reduces the use of air conditioners. Additionally, Choi et al. [152] also discussed that the optimization of the air flow organization has a significant effect toward the heat dissipation efficiency of the VCT.

Zhang et al. [165] studied the envelope design of a BS located in Guangzhou and recommended that for a BS where ventilation is not possible, a thermal management solution can be achieved through a combined design of a high heat transfer coefficient and a low solar absorption roof and wall. A similar study has also been conducted by Tu et al. [154] through energy performance modeling of a BS based on two extreme climate conditions-Harbin (representing the severe cold region) and Guangzhou (representing the hot region). Two types of air conditioning systems are compared and analyzed using Designer's Simulation Toolkit (DeST) and the results showed that the selection of the BS envelope is influenced by the outdoor climate, the indoor heat dissipation rate, and the type of air conditioning used. Additionally, Tu et al. [154] also recommended that a heat pipe-assisted air conditioning system be used for the cooling of the BS shelter due to its high outdoor cooling capacity.

As discussed by Darwiche and Shaik [155], the factors that affect the design of air conditioning systems are solar radiation, wind speed, objects surrounding the shelter (e.g., shading, ground reflections, trees, etc.), and the BS shelter design (e.g., surface area, shape, paint, etc.). Additionally, Darwiche and Shaik [155] also discussed the common types of cooling systems used in off-grid BSs, alongside their advantages and disadvantages, as represented in Table 1.

The extreme high temperature application of power supply components (e.g., when deploying PV-fuel cell or PV-wind-hydrogen systems at extreme hot conditions) can also aggravate the degradation of the PEM fuel cell membrane and catalyst, therefore reducing the performance of the PEM fuel cells [51,144,169]. Similarly, for batteries experiencing extreme hot conditions, issues such as overheating (which can cause risks like explosions and fire due to thermal runaway), degradation, and poor performance of the batteries, which arise from the sluggish kinetics of charge transfer, low electrolyte conductivity, and the reduced solid-state of lithium diffusivity, are critical and need to be addressed when designing appropriate power supply systems for off-grid BSs [59,63,170-173]. Commonly, the cooling of these power supply components is done using strategies such as cooling with air, cooling with liquid, cooling with phase change, and edge cooling, and each of these cooling strategies has its own advantages and disadvantages [144,169,174,175]. 
Table 1. Cooling types for off-grid base station applications.

\begin{tabular}{|c|c|c|}
\hline Cooling Types & Advantages & Disadvantages \\
\hline \multirow{2}{*}{ Exhaust fans } & \multirow{2}{*}{ Low cost } & Overheating \\
\hline & & Potential outdoor contaminants risk \\
\hline \multirow{3}{*}{ Vortex cooler } & No moving parts & Low efficiency \\
\hline & Highly reliable & Limited cooling capacity \\
\hline & & Highly dependable on compressed air \\
\hline \multirow{2}{*}{ Peltier cooler } & No moving parts & Low efficiency \\
\hline & Highly reliable & Limited cooling capacity \\
\hline \multirow{2}{*}{$\begin{array}{c}\text { Natural convection } \\
\text { (passive cooled systems) }\end{array}$} & \multirow{2}{*}{ No moving parts } & Large footprint \\
\hline & & High initial cost \\
\hline \multirow{2}{*}{$\begin{array}{l}\text { Phase change materials } \\
\text { (passive cooled systems) }\end{array}$} & No moving parts & May not function properly if not correctly \\
\hline & Small footprint & packed \\
\hline \multirow{2}{*}{ DC-powered air conditioners } & $\begin{array}{l}\text { Higher cooling capacity } \\
\text { than any other system }\end{array}$ & Moving parts, specific maintenance is required \\
\hline & $\begin{array}{l}\text { Able to cool shelter to } \\
\text { human comfort level }\end{array}$ & Large footprint required for the solar panels \\
\hline
\end{tabular}

\subsubsection{Heating}

Energy efficiency measures to be considered for telecommunication BSs are different than those usually taken into account in residential or commercial buildings. This is because the energy consumption of the BS is very high due to its high inner heat density and special operating schedule [165]. For the heating of the BS components, limited studies were found in regard to the heating systems. This is because previous literature was more focused on the cooling of the BS components.

Nakao et al. [166] suggested a thermal control wall that uses a two-phase loop-type siphon system embedded in the wall in order to help regulate the temperature of a BS shelter, especially when the outdoor temperature is higher than the ambient temperature or during the winter period when the ambient temperature is lower than the suggested temperature. When any of these conditions happen, the valve that controls the refrigerant circulation in the thermo-siphon will shut off and the thermal control wall will prevent heat from dissipating into the atmosphere, thus heating the BS shelter accordingly. Flores and Han designed a conventional flat-plate heat exchanger [157]. However, due to its high failure rates and high maintenance costs, other alternatives are used or proposed for the heating of the BSs.

Alternatively, the heat loss from BS electronic equipment can be the heat source for heating the BS and its components. This is because the heat can be delivered through convection and radiation methods, as discussed by Zhang et al. [165]. To calculate the convective heat loss, parameters such as airflow rates, ambient room temperatures (inlet air temperatures), and outlet air temperatures are used in the calculation, whereas the heat loss through radiation (which is usually negligible) can be calculated by using the exterior surface temperature of the BS envelope [165]. Likewise, Karasseferian and Desjardins [156] suggested that the heat recovery system be used to thermally manage the BS components, while Pell et al. [158] proposed that the heating of the BS components was made possible by the heat recovered from the power amplifiers. 
Dukhan et al. [160] suggested a few configurations on the heating of the battery and the cooling of the BS electronic equipment using a vortex tube. The mechanism of such a system works by generating high pressured cold air using a vortex tube which pushes the heat (dissipated by the BS electronic equipment) away from the BS shelter to the battery chamber in order to warm up the batteries during extreme cold operation. Additionally, the heat can be stored using phase change materials (PCMs) as thermal storage for later use when heating of the battery is necessary.

For power supply components (e.g., PEM fuel cells) operating in extreme cold conditions, issues such as cold start-up, water or ice formation, melting on the catalyst layer, and membrane dehydration are among the challenges present when running the PEM fuel cells at such conditions [142,146,176,177]. Kagami et al. [178] found that a successful self-start without the presence of external heating could only be achieved with the start-up temperature of $-5{ }^{\circ} \mathrm{C}$. However, for start-up temperatures lower than $-5{ }^{\circ} \mathrm{C}$, external heating is needed to warm up the PEM fuel cell. Similarly, batteries operating at low temperature conditions tend to experience reduced cell energy and power capability due to the significant increase of internal resistance in the batteries [170]. As discussed by Pesaran et al. [179], the heat generated in a battery consists of electrochemical reactions, phase changes, mixing effects, and Joule heating, and the heat transfer of the battery can be represented by Equation (2) below:

$$
m C_{p} \frac{d T_{s}}{d t}=\text { Heat }_{\text {gen }}-h A\left(T_{s}-T_{a}\right)-e \delta A\left(T_{s}^{4}-T_{a}{ }^{4}\right)-Q_{\text {ext_conduction }}
$$

where $m C_{p} \frac{d T_{s}}{d t}$ is the rate of temperature change, Heatgen is the rate of internal heat generation, $T_{s}$ is the battery temperature, $T_{a}$ is the ambient temperature, $h A\left(T_{s}-T_{a}\right)$ is the convection heat rate, $e \delta A\left(T_{s}{ }^{4}-T_{a}{ }^{4}\right)$ is the radiation heat rate, and $Q_{\text {ext_conduction }}$ is the conduction heat rate.

Additionally, warming up the batteries for an initial discharge due to low-temperature operation can be done through strategies such as using battery power (i.e., self-internal, convective, and mutual pulse heating), and thermal blankets or additional auxiliary heating (e.g., heat recovery of BS electronic equipment or PEM fuel cells) [170,180].

\subsection{Operation and Control Strategy}

Effective operation and control strategies within the power supply system can be done by making priority-based decisions in order to prioritize the order of energy generation resources [181]. Typically, the aim of operation and control strategies of the power supply system is to fully utilize the free available energy resources, then utilize the energy stored in the energy storage (i.e., batteries), and finally convert the energy from another device (i.e., converting hydrogen to electricity via fuel cells) [181]. This is to ensure that an effective management of energy flow can be achieved for a stable and a reliable power supply system at the lowest cost possible [107,127]. Additionally, the complexity of the operational and control strategies increases as the configuration of the power supply system enlarges [25]. In a paper discussed by Bajpai and Dash [107], the key parameters involved in designing optimal operation and control strategies are energy resources (e.g., renewable energy), economic factors (e.g., capital cost, O\&M cost, and lifetime period), and storage devices (e.g., state of charge (SOC), pressure level of hydrogen tank, and days of autonomy).

For the application of power supply systems, the common control strategies used for this purpose are component-level control strategies and system-level control strategies [103]. The component-level 
control strategies are commonly applied at the converter, where most of the generators (i.e., PVs, fuel cells, batteries) are interconnected to the system, and the converter is responsible for establishing the voltage and frequency references of the system alongside keeping it constant at all times [103]. For system-level control strategies, factors such as load, estimation of energy generation, unit commitment, economic dispatch, and security constraints are taken into consideration to ensure the power supply system can operate at an efficient manner [103]. The system-level control strategies can be classified into centralized control strategies and decentralized control strategies, and the centralized control strategies allow communication between the control center and the local controllers. Information like power output from the generators, voltage and frequency deviations, load demand estimations, and charging status of the storage systems is shared between the local controllers as well as the control center.

For decentralized control strategies, a control center is not needed as intelligent decisions are made based on the communication between components. According to Tan et al. [103], there are two types of strategy in the decentralized control which are droop control strategy and multi-agent control strategy. The droop control strategy is the most commonly used strategy and the system frequency and voltage magnitude are maintained according to reactive and active power deviation based on pre-specified requirements in order to overcome some of the technical challenges, such as frequency and voltage deviation, impact of line impedance, non-linear loads, and inertia coordination [103]. For the multi-agent strategy, embedded local intelligence allows the evolution of the decentralized control strategy where the system components communicate between one another through global coordination [182]. This allows the power supply system to operate at any given conditions.

A wide range of literature can be found relating to the study and the application of the operation and control strategies of power supply systems specifically for BS application. For instance, Okundamiya et al. [127] proposed an optimum model of control strategies for a hybrid PV-wind system. The key idea of the strategy was to ensure that the energy generation must be leveled between the energy resource and the energy distribution in order to satisfy the load demand while maintaining the reliability of the system operation [127,183]. As the control strategy for the system uses a GA-based technique, the peak power trackers (PPTs) are responsible for keeping the PVs and wind turbine generators capable of operating at their maximum operating levels. This resulted in an excellent energy improvement with an excess energy capacity of only $6 \%-17 \%$ and a fairly reasonable cost of electricity value of the system at $\$ 0.12 / \mathrm{kWh}$, compared to the cost of electricity of the utility grid at $\$ 0.33 / \mathrm{kWh}$ and diesel generator at $\$ 0.02 / \mathrm{kWh}[183]$.

Castañeda et al. [87] proposed three control strategies, which are modeled using Simulink Design Optimization (SDO) of MATLAB, for managing the energy flow of a hybrid PV-hydrogen-battery system. Control strategy 1 uses the simplest control scheme to maintain the battery's SOC at an optimum level and the charging and discharging of the battery are used as control variables of the system. Control strategy 2 was designed to maintain an optimum level at the hydrogen tank and the battery's SOC; control strategy 3 is the most complex control scheme and it is based on techno-economic operating modes (i.e., the cycling cost of energy in the battery, fuel cells, and electrolyzer). As a result, Castañeda et al. [87] found that control strategy 2 gives the highest efficiency (at around $42 \%$ ) for the whole system.

In a study by Li et al. [89], the control strategy for three different hybrid power supply systems (i.e., PV-fuel cells-battery, PV-battery, and PV-fuel cells systems) is simulated and analyzed through the 
energy balance of the systems throughout the year. The maximum system efficiency and the minimum system costs are taken into consideration when simulating the strategy in order to satisfy the techno-economic analysis of the system. The results showed that the PV-fuel-cell-battery system was found to have higher system efficiency at the lowest cost compared to the other two configurations.

Caisheng and Nehrir [184] discussed in their literature that the operation and control strategy for an AC-linked hybrid PV-wind-fuel cell system varies according to factors like seasonal scenarios (i.e., winter and summer). Based on the simulation model, a control strategy was designed to manage the energy flow within the system and the simulation model was carried out using MATLAB/Simulink. The fuel cell system acts as backup energy generation and the electrolyzer acts as a dump load based on the excess energy available to produce hydrogen. The simulation results showed that effective operation and control strategy of the hybrid power supply system managed to be achieved alongside its feasible outputs.

\section{Conclusions}

In this paper, an up-to-date review of different power supply solutions for off-grid BSs was presented. The key aspects in choosing and designing appropriate power supply solutions for the BSs were discussed accordingly. These solutions include diesel generators, renewable energy systems (e.g., PV or wind systems), hybrid power supply systems (i.e., PV-wind, PV-diesel, PV-wind-diesel, and PV-fuel cell systems), and energy storage solutions that were specific to the electrochemical type of energy storage classification such as batteries, hydrogen systems, and hybrid energy storage systems.

As the BSs were liable for their GHG emissions, their energy efficient goals could be achieved through measures such as further reductions in BS energy consumption, which would possibly reduce the O\&M costs and improve the QoS of BSs' coverage and the amounts of emissions that were associated with them. Additionally, it was discussed that by understanding the importance of the key design aspects including the pre-feasibility study and the thermal management of BSs, which involves the heating and cooling of the BS components, the energy consumption of the BSs can be further reduced. This possibly helps increase the reliability of the BS, which is very critical as $99.99 \%$ reliability is expected for remote telecommunication applications.

In this review paper, the sizing and the optimization of the power supply systems were also discussed as both elements highlight the importance of confirming the feasibility, reliability, and emission-free power supply systems for off-grid BSs. Hence, various sizing and optimization methods were also reviewed accordingly in order to cover the common methods that have been or could be applied for these purposes. Another important element was the operational and control strategy, through which managing the energy flow in the power supply system can be optimized, leading to further reductions in total capital and O\&M costs. Accordingly, through an ideal operational and control strategy, the efficiency of the power supply system could be increased. This would validate the concepts of using both "green" and energy efficient BSs.

Other promising energy efficiency technologies and approaches that were highlighted in this paper are summarized in Table 2. The key areas of such promising technologies/approaches are comprised of power supply technologies, energy storage technologies, high efficient devices/equipment, and energy management and thermal management approaches. 
Table 2. Summary of promising technologies/approaches for energy efficient base stations.

\begin{tabular}{|c|c|c|c|c|c|}
\hline Key Areas & Technologies/Approaches & & Advantages & Disadvantages & Literature Reviews \\
\hline \multirow{2}{*}{ Power supply technologies } & New generation small wind turbines & • & $\begin{array}{cc}\bullet & \text { Lightweight } \\
\bullet & \text { Highly efficient } \\
\text { Able to supply power at much lower wind speeds }\end{array}$ & $\begin{array}{l}\text { Limited application (e.g., for low powered } \\
\text { BSs) }\end{array}$ & {$[27,29,30]$} \\
\hline & Hybrid PV-fuel cell system & & $\begin{array}{ll}\text { - } & \text { High efficiency } \\
- & \text { High modularity } \\
\text { - } & \text { High fuel flexibility }\end{array}$ & $\begin{array}{l}\text { - } \quad \text { Expensive } \\
\text { Slow dynamic in fuel cell system }\end{array}$ & {$[33,49,185]$} \\
\hline \multirow{3}{*}{ Energy storage technologies } & New generation Li-ion battery & & $\begin{array}{l}\text { - } \\
\begin{array}{l}\text { - } \\
\text { - }\end{array} \text { How weight footprint } \\
\text { Storage efficiency close to } 100 \% \\
\end{array}$ & $\begin{array}{l}\bullet \quad \text { High cost } \\
\text { Unfavorable effect of deep discharging to the } \\
\text { battery's lifetime }\end{array}$ & {$[55,58,170,186]$} \\
\hline & $\begin{array}{l}\text { Hydrogen-based energy storage system } \\
\text { (i.e., fuel cell-electrolyzer) }\end{array}$ & $\begin{array}{l}\bullet \\
\bullet \\
\bullet\end{array}$ & $\begin{array}{l}\text { Able to store and generate electricity } \\
\text { simultaneously } \\
\text { Emission free (when using hydrogen as fuel) } \\
\text { Can be used for various type of applications } \\
\text { Cost of energy storage is cheaper than battery }\end{array}$ & High capital cost & {$[86]$} \\
\hline & $\begin{array}{c}\text { Hybrid energy storage system } \\
\text { (e.g., PV-hydrogen-battery system) }\end{array}$ & • & $\begin{array}{cc}\text { Suitable for long-term and short-term storage } \\
\text { - } & \text { High reliability } \\
\text { - } & \text { Low O\&M costs }\end{array}$ & High capital cost & {$[39,41,86]$} \\
\hline \multirow[t]{2}{*}{ High efficient devices/equipment } & Multi-input power converters & • & $\begin{array}{l}\text { - } \quad \text { Low cost } \\
\text { - } \quad \text { High power density } \\
\text { Helps to reduce number of components in } \\
\text { power supply systems }\end{array}$ & $\begin{array}{l}\text { Faulty at the open-circuit switch can reduce } \\
\text { the availability of power supply system. }\end{array}$ & {$[38]$} \\
\hline & Cognitive radio technology & $\bullet$ & $\begin{array}{l}\text { Helps to improve QoS of BSs } \\
\text { Small coverage radius leads to improvement in } \\
\text { spectrum efficiency }\end{array}$ & $\begin{array}{l}\text { Wide coverage radius leads to low efficiency } \\
\text { of spectrum reuse }\end{array}$ & {$[15,16,97]$} \\
\hline
\end{tabular}


Table 2. Cont.

\begin{tabular}{|c|c|c|c|c|}
\hline Key Areas & Technologies/Approaches & Advantages & Disadvantages & Literature Reviews \\
\hline \multirow[t]{2}{*}{ Energy management } & Device-to-device (D2D) communication & $\begin{array}{cc}\text { - } & \text { Helps to reduce energy consumption of BS } \\
\text { - } & \text { Increase throughput and spectrum efficiency } \\
\text { - } & \text { Increase energy efficiency of BSs }\end{array}$ & $\begin{array}{l}\text { Causes interference with the cellular network } \\
\text { due to spectrum sharing }\end{array}$ & {$[96,187]$} \\
\hline & Sleep mode or deep-idle mode & $\begin{array}{cc}\text { - } & \text { Effectively reduce energy consumption of BSs } \\
\text { - } & \text { Practical for dense BSs deployments } \\
\end{array}$ & Risk of reducing the QoS & {$[92,93,188,189]$} \\
\hline \multirow[b]{2}{*}{ Thermal management } & $\begin{array}{l}\text { Free cooling using phase change } \\
\text { materials (PCMs) and heat pipes }\end{array}$ & $\begin{array}{cc}\text { - } & \text { Low to zero energy usage } \\
& \text { Low O\&M costs } \\
\end{array}$ & $\begin{array}{l}\text { May not function properly if not } \\
\text { correctly installed }\end{array}$ & {$[155,190,191]$} \\
\hline & Heat recovery using thermo-syphon & $\begin{array}{l}\text { Low to zero energy usage } \\
\text { - } \quad \text { Can be used for thermally managed BS } \\
\text { shelter/cabinets, BS equipment and power supply } \\
\text { components } \\
\text { L } \quad \text { Low O\&M costs }\end{array}$ & $\begin{array}{l}\text { Extremely challenging to capture the heat in } \\
\text { real life applications }\end{array}$ & {$[163,192-195]$} \\
\hline
\end{tabular}




\section{Author Contributions}

Asma Mohamad Aris is the first author who is responsible in writing the main parts of the paper alongside conducting extensive literature survey regarding sustainable power supply and energy storage solutions for off-grid base stations as well as the key aspects of power supply system design.

Bahman Shabani's role in the paper was exclusively advisory due to his wide experience in the area of sustainable power supply and energy storage solutions for off-grid applications. In addition, Bahman Shabani also contributed broadly in defining the framework of this paper, especially in the context of sizing and optimization of power supply system and thermal management of base stations.

\section{Conflicts of Interest}

The authors declare no conflict of interest.

\section{References}

1. Meo, M.; Le Rouzic, E.; Cuevas, R.; Guerrero, C. Research challenges on energy-efficient networking design. Comput. Commun. 2014, 50, 187-195.

2. Webb, M. Smart 2020: Enabling the low carbon economy in the information age; The Climate Group: London, UK, 2008; pp 1-87.

3. Hasan, Z.; Boostanimehr, H.; Bhargava, V.K. Green cellular networks: A survey, some research issues and challenges. Commun. Surv. Tutor. IEEE 2011, 13, 524-540.

4. Lambert, S.; Van Heddeghem, W.; Vereecken, W.; Lannoo, B.; Colle, D.; Pickavet, M. Worldwide electricity consumption of communication networks. Opt. Express 2012, 20, B513-B524.

5. Kusakana, K.; Vermaak, H.J. Hybrid renewable power systems for mobile telephony base stations in developing countries. Renew. Energy 2013, 51, 419-425.

6. Cisco visual networking index forecast projects nearly 11-fold increase in global mobile data traffic from 2013 to 2018; Cisco Public: San Francisco, CA, US, 2014.

7. Fehske, A.; Fettweis, G.; Malmodin, J.; Biczok, G. The global footprint of mobile communications: The ecological and economic perspective. Commun. Mag. IEEE 2011, 49, 55-62.

8. Valdecantos, C.; Gaspar, R. The rise of green mobile telecom towers. Available online: http://consultantvalueadded.com/2013/01/16/guest-post-the-rise-of-green-mobile-telecom-towers/ (accessed on 1 September 2015).

9. Murthy, C.R.; Kavitha, D.C. A survey of green base stations in cellular networks. IRACST Int. J. Comput. Netw. Wirel. Commun. (IJCNWC). 2012, 2, 232-236.

10. Lorincz, J.; Bule, I. Renewable energy sources for power supply of base station sites. Int. J. Bus. Data Commun. Netw. 2013, 9, 53-74.

11. Piro, G.; Miozzo, M.; Forte, G.; Baldo, N.; Grieco, L.A.; Boggia, G.; Dini, P. Hetnets powered by renewable energy sources: Sustainable next-generation cellular networks. Internet Comput. IEEE 2013, 17, 32-39.

12. Auer, G.; Giannini, V.; Desset, C.; Godor, I.; Skillermark, P.; Olsson, M.; Imran, M.A.; Sabella, D.; Gonzalez, M.J.; Blume, O. How much energy is needed to run a wireless network? Wirel. Commun. IEEE 2011, 18, 40-49. 
13. Al Haj Hassan, H.; Nuaymi, L.; Pelov, A. Renewable Energy in Cellular Networks: A Survey. In Proceedings of the 2013 IEEE Online Conference on Green Communications (GreenCom), Piscataway, NJ, USA, 29-31 October 2013; pp. 1-7.

14. Taverner, D. Community power: Using mobile to extend grid; Groupe Speciale Mobile Association (GSMA): London, UK, 2010; pp 1-77.

15. Zhang, H.; Jiang, C.; Mao, X.; Chen, H. Interference-limited resource optimization in cognitive femtocells with fairness and imperfect spectrum sensing. Veh. Technol. IEEE Trans. 2015, PP, 1.

16. Haijun, Z.; Chunxiao, J.; Beaulieu, N.C.; Xiaoli, C.; Xianbin, W.; Quek, T.Q.S. Resource allocation for cognitive small cell networks: A cooperative bargaining game theoretic approach. IEEE Trans. Wirel. Commun. 2015, 14, 3481-3493.

17. Alsharif, M.; Nordin, R.; Ismail, M. Energy optimisation of hybrid off-grid system for remote telecommunication base station deployment in malaysia. J. Wirel. Commun. Netw. 2015, 2015, 1-15.

18. Rijssenbeek, J.; Wiegman, H.; Hall, D.; Chuah, C.; Balasubramanian, G.; Brady, C.; IEEE. Sodium-metal halide batteries in diesel-battery hybrid telecom applications. In Proceedings of the 2011 IEEE 33rd International Telecommunications Energy Conference (INTELEC), Amsterdam, The Netherlands, 9-13 October 2011.

19. Nordin, H.; Lindemark, B. System reliability, dimensioning and environmental impact of diesel engine generator sets used in telecom applications. In Proceedings of the 21st International Telecommunication Energy Conference, 1999. (INTELEC '99), Copenhagen, Kingdom of Denmark, 6-9 June 1999; p. 7.

20. Conteh, A.B.M. Overcoming the vast challenge of deploying a mobile network in the democratic republic of congo (drc). In Proceedings of VODACOM Singapore Annual Meeting, Singapore, 17 September 2006.

21. Goel, S.; Ali, S.M. Cost analysis of solar/wind/diesel hybrid energy systems for telecom tower by using homer. Int. J. Renew. Energy Res. (IJRER) 2014, 4, 305-311.

22. Moghavvemi, M.; Ismail, M.S.; Murali, B.; Yang, S.S.; Attaran, A.; Moghavvemi, S. Development and optimization of a pv/diesel hybrid supply system for remote controlled commercial large scale fm transmitters. Energy Convers. Manag. 2013, 75, 542-551.

23. Karakoulidis, K.; Mavridis, K.; Bandekas, D.V.; Adoniadis, P.; Potolias, C.; Vordos, N. Techno-economic analysis of a stand-alone hybrid photovoltaic-diesel-battery-fuel cell power system. Renew. Energy 2011, 36, 2238-2244.

24. Kaldellis, J.; Ninou, I. Energy balance analysis of combined photovoltaic-diesel powered telecommunication stations. Int. J. Electr. Power Energy Syst. 2011, 33, 1739-1749.

25. Arul, P.G.; Ramachandaramurthy, V.K.; Rajkumar, R.K. Control strategies for a hybrid renewable energy system: A review. Renew. Sustain. Energy Rev. 2015, 42, 597-608.

26. GSMA. Green power for mobile bi annual report 2014; Groupe Speciale Mobile Association (GSMA): London, UK, 2014.

27. Vilander, M. Blowing your way wind-powered base stations. Available online: http://www.connect-world.com/ cwiml/index.php/press-releases/item/27293-itu-tacklesfinancial-inclusion-for-2-billion-people (accessed on 1 September 2015). 
28. Paudel, S.; Shrestha, J.; Neto, F.J.; Ferreira, J.A.; Adhikari, M. Optimization of hybrid pv/wind power system for remote telecom station. In Proceedings of the 2011 International Conference on Power and Energy Systems (ICPS), Chennai, Italy, 22-24 December 2011; pp. 1-6.

29. Singh, R.K.; Ahmed, M.R. Blade design and performance testing of a small wind turbine rotor for low wind speed applications. Renew. Energy 2013, 50, 812-819.

30. Vilander, M. Wind turbine energy for telecom: A sustainable solution for the future. In Proceedings of GM EMEA/SVP Global Telecom, Cape Town, South Africa, 8 November 2011. http://www.gsma.com/mobilefordevelopment/wp-content/uploads/2012/06/Zephyr1.pdf (accessed on 1 September 2015).

31. Faruk, N.; Ayeni, A.; Muhammad, M.; Abdulkarim, A.; Moses, O. Hybrid power systems for cell sites in mobile cellular networks. J. Select. Areas Renew. Sustain. Energy 2012, 8-12.

32. Bian, S.; Wang, X.; Congiatu, M. In An off-grid base station powered by sun, wind, and water, Telecommunications Energy Conference 'Smart Power and Efficiency' (INTELEC), Proceedings of 2013 35th International, Hamburg, Germany, 2013; VDE: Hamburg, Germany, pp 1-5.

33. Rekioua, D.; Bensmail, S.; Bettar, N. Development of hybrid photovoltaic-fuel cell system for stand-alone application. Int. J. Hydrog. Energy 2014, 39, 1604-1611.

34. Yang, H.X.; Lu, L.; Burnett, J. Weather data and probability analysis of hybrid photovoltaic-wind power generation systems in hong kong. Renew. Energy 2003, 28, 1813-1824.

35. Mohammed, Y.S.; Mustafa, M.W.; Bashir, N. Hybrid renewable energy systems for off-grid electric power: Review of substantial issues. Renew. Sustain. Energy Rev. 2014, 35, 527-539.

36. Hashimoto, S.; Yachi, T.; Tani, T. A new stand-alone hybrid power system with wind generator and photovoltaic modules for a radio base station. In Proceedings of Telecommunications Energy Conference, 2004. INTELEC 2004. 26th Annual International, 19-23 September, 2004; IEEE: pp. 254-259.

37. Yu, W.; Qian, X. Design of $3 \mathrm{kw}$ wind and solar hybrid independent power supply system for $3 \mathrm{~g}$ base station. In Proceedings of Knowledge Acquisition and Modeling, 2009. KAM'09. Second International Symposium on Wuhan, Hubei, China, 2009; IEEE: pp 289-292.

38. Ribeiro, E.; Marques Cardoso, A.J.; Boccaletti, C. Fault diagnosis in a multi-input power interface for a photovoltaic wind supply system for telecommunications. In Proceedings of 35th International Telecommunications Energy Conference 'Smart Power and Efficiency' (INTELEC), Hamburg, Germany, 13-17 Oct. 2013, 2013; pp 1-6.

39. Bezmalinović, D.; Barbir, F.; Tolj, I. Techno-economic analysis of pem fuel cells role in photovoltaic-based systems for the remote base stations. Int. J. Hydrog. Energy 2013, 38, 417-425.

40. Husain, S.M.; Sharma, D.K. Techno-economic analysis of solar pv/diesel hybrid energy system for electrification of television substation - "a case study of nepal television substation at ilam". Proceedings of IOE Graduate Conference, Tribhuvan University, Nepal: 2014; pp 420-428,

41. Guinot, B.; Champel, B.; Montignac, F.; Lemaire, E.; Vannucci, D.; Sailler, S.; Bultel, Y. Techno-economic study of a pv-hydrogen-battery hybrid system for off-grid power supply: Impact of performances' ageing on optimal system sizing and competitiveness. Int. J. Hydrog. Energy 2015, 40, 623-632.

42. Askari, I.B.; Ameri, M. Optimal sizing of photovoltaic-battery power systems in a remote region in kerman, iran. Proc. Inst. Mech. Eng. 2009, 223, 563-570. 
43. Dufo-López, R.; Bernal-Agustín, J.L. Design and control strategies of pv-diesel systems using genetic algorithms. Sol. Energy 2005, 79, 33-46.

44. Dufo-López, R.; Bernal-Agustín, J.L.; Yusta-Loyo, J.M.; Domínguez-Navarro, J.A.; Ramírez-Rosado, I.J.; Lujano, J.; Aso, I. Multi-objective optimization minimizing cost and life cycle emissions of stand-alone pv-wind-diesel systems with batteries storage. Appl. Energy 2011, 88, 4033-4041.

45. Bitterlin, I.F. Modelling a reliable wind/pv/storage power system for remote radio base station sites without utility power. J. Power Sources 2006, 162, 906-912.

46. Goel, S.; Ali, S.M. Hybrid energy systems for off-grid remote telecom tower in odisha, india. Int. J. Ambient Energy 2013, 1-7.

47. Sharma, A.; Singh, A.; Khemariya, M. Homer optimization based solar pv; wind energy and diesel generator based hybrid system. Int. J. Soft Comput. Eng. (IJSCE) 2013, 3,199-204.

48. Olatomiwa, L.; Mekhilef, S.; Huda, A. Optimal sizing of hybrid energy system for a remote telecom tower: A case study in nigeria. In Proceedings of the 2014 IEEE Conference on Energy Conversion (CENCON), Johor Bahru, Malaysia, 13-14 October 2014; pp. 243-247.

49. Jiang, Z. Power management of hybrid photovoltaic-fuel cell power systems. In Proceedings of the 2006 Power Engineering Society General Meeting, Montreal, QC, Canada, 18-22 June 2006; pp. 1-5.

50. Shabani, B.; Andrews, J. Standalone solar-hydrogen systems powering fire contingency networks. Int. J. Hydrog Energy 2015, 40, 5509-5517.

51. Shabani, B.; Andrews, J. Hydrogen and fuel cells. In Energy sustainability through green energy, Sharma, A.; Kar, S.K., Eds.; Springer India: New Delhi, India, 2015; pp 453-491.

52. Lehman, P.; Chamberlin, C.; Zoellick, J.; Engel, R.; Rommel, D. Fuel cell/photovoltaic integrated power system for a remote telecommunications repeater. In Proceedings of the 14th World Hydrogen Energy Conference, Montreal, QC, Canada, 9-14 June 2002.

53. Belmili, H.; Haddadi, M.; Bacha, S.; Almi, M.F.; Bendib, B. Sizing stand-alone photovoltaic-wind hybrid system: Techno-economic analysis and optimization. Renew. Sustain. Energy Rev. 2014, 30, 821-832.

54. Koutitas, G.; Demestichas, P. A review of energy efficiency in telecommunication networks. Telfor J. 2010, 2, 2-7.

55. Yekini Suberu, M.; Wazir Mustafa, M.; Bashir, N. Energy storage systems for renewable energy power sector integration and mitigation of intermittency. Renew. Sustain. Energy Rev. 2014, 35, 499-514.

56. Zhang, X.; Kong, X.; Li, G.; Li, J. Thermodynamic assessment of active cooling/heating methods for lithium-ion batteries of electric vehicles in extreme conditions. Energy 2014, 64, 1092-1101.

57. Tin, T.; Sovacool, B.K.; Blake, D.; Magill, P.; El Naggar, S.; Lidstrom, S.; Ishizawa, K.; Berte, J. Energy efficiency and renewable energy under extreme conditions: Case studies from antarctica. Renew. Energy 2010, 35, 1715-1723.

58. Ji, Y.; Zhang, Y.; Wang, C.-Y. Li-ion cell operation at low temperatures. J. Electrochem. Soc. 2013, 160, A636-A649.

59. Wang, Q.; Ping, P.; Zhao, X.; Chu, G.; Sun, J.; Chen, C. Thermal runaway caused fire and explosion of lithium ion battery. J. Power Sources 2012, 208, 210-224. 
60. Eaves, S.S.; Mlyniec, S.; IEEE. Lithium-ion batteries in telecom hybrid power systems. In Proceedings of the 2011 IEEE 33rd International Telecommunications Energy Conference (INTELEC), Amsterdam, Netherlands, 9-13 October 2011.

61. Divya, K.C.; Østergaard, J. Battery energy storage technology for power systems-an overview. Elec. Power Syst. Research 2009, 79, 511-520.

62. Rouillard, J.; St-Pierre, C.; Geoffroy, D.; Carignan, C. Testing of lithium polymer batteries in outside power cabinet for telecommunication system. In Proceedings of the 21 st International Telecommunication Energy Conference (INTELEC '99), Copenhagen, Kingdom of Denmark, 6-9 June 1999; p. 522.

63. Rao, Z.; Wang, S. A review of power battery thermal energy management. Renew. Sustain. Energy Rev. 2011, 15, 4554-4571.

64. Ng, P.K.; Xie, L. Lithium ion battery for telecommunications applications. 2004.

65. Eaves, S.; Shaffer, D. Lithium-ion batteries for telecom applications. In Proceedings of the 29th International Telecommunications Energy Conference, 2007 (INTELEC 2007), Rome, Italy, 30 September-4 October 2007; pp. 708-712.

66. Shahirinia, A.H.; Tafreshi, S.M.M.; Gastaj, A.H.; Moghaddomjoo, A.R. Optimal sizing of hybrid power system using genetic algorithm. In Proceedings of 2005 International Conference on Future Power Systems, Amsterdam, The Netherlands, 18 November. 2005, p. 6.

67. Merei, G.; Berger, C.; Sauer, D.U. Optimization of an off-grid hybrid pv-wind-diesel system with different battery technologies using genetic algorithm. Sol. Energy 2013, 97, 460-473.

68. Bak, T.; Nowotny, J.; Rekas, M.; Sorrell, C.C. Photo-electrochemical hydrogen generation from water using solar energy. Materials-related aspects. Int. J. Hydrog. Energy 2002, 27, 991-1022.

69. Ghosh, P.C.; Emonts, B.; Stolten, D. Comparison of hydrogen storage with diesel-generator system in a pv-wec hybrid system. Sol. Energy 2003, 75, 187-198.

70. Agbossou, K.; Kolhe, M.; Hamelin, J.; Bose, T.K. Performance of a stand-alone renewable energy system based on energy storage as hydrogen. Energy Convers. IEEE Trans. 2004, 19, 633-640.

71. Kaviani, A.K.; Baghaee, H.; Riahy, G. Design and optimal sizing of a photovoltaic/wind generator system using particle swarm optimization. In Proceedings of the 22nd Power System Conference (PSC), Tehran, Iran, 19-21 November 2007; pp. 19-21.

72. Brunet, Y. Energy storage. John Wiley \& Sons: Somerset, NJ, USA, 2013.

73. Vosen, S.R.; Keller, J.O. Hybrid energy storage systems for stand-alone electric power systems: Optimization of system performance and cost through control strategies. Int. J. Hydrog. Energy 1999, 24, 1139-1156.

74. Garrigós, A.; Lizán, J.L.; Blanes, J.M.; Gutiérrez, R. Combined maximum power point tracking and output current control for a photovoltaic-electrolyser dc/dc converter. Int. J. Hydrog. Energy 2014, 39, 20907-20919.

75. Gómez, G.; Martínez, G.; Gálvez, J.L.; Gila, R.; Cuevas, R.; Maellas, J.; Bueno, E. Optimization of the photovoltaic-hydrogen supply system of a stand-alone remote-telecom application. Int. J. Hydrog. Energy 2009, 34, 5304-5310.

76. Hollmuller, P.; Joubert, J.-M.; Lachal, B.; Yvon, K. Evaluation of a $5 \mathrm{kw}$ p photovoltaic hydrogen production and storage installation for a residential home in switzerland. Int. J. Hydrog. Energy 2000, 25, 97-109. 
77. Khan, M.J.; Iqbal, M.T. Pre-feasibility study of stand-alone hybrid energy systems for applications in newfoundland. Renew. Energy 2005, 30, 835-854.

78. Kashefi Kaviani, A.; Riahy, G.H.; Kouhsari, S.M. Optimal design of a reliable hydrogen-based stand-alone wind/pv generating system, considering component outages. Renew. Energy 2009, 34, 2380-2390.

79. Barbir, F. Pem electrolysis for production of hydrogen from renewable energy sources. Sol. Energy 2005, 78, 661-669.

80. Cano, A.; Jurado, F.; Sanchez, H.; Castaneda, M.; Fernandez, L.M. Sizing and energy management of a stand-alone pv/hydrogen/battery-based hybrid system. In Proceedings of the 2012 International Symposium on Power Electronics, Electrical Drives, Automation and Motion (SPEEDAM), Sorrento, Italy, 20-22 June 2012; pp. 969-973.

81. Andrews, J.; Shabani, B. The role of hydrogen in a global sustainable energy strategy. Wiley Interdiscip. Rev. Energy Environ. 2014, 3, 474-489.

82. Agbossou, K.; Chahine, R.; Hamelin, J.; Laurencelle, F.; Anouar, A.; St-Arnaud, J.-M.; Bose, T. Renewable energy systems based on hydrogen for remote applications. J. Power Sources 2001, 96, $168-172$.

83. Dokkar, B.; Negrou, B.; Settou, N.; Imine, O.; Chennouf, N.; Benmhidi, A. Optimization of pem fuel cells for pv-hydrogen power system. Energy Procedia 2013, 36, 798-807.

84. Sundmacher, K. Fuel cell engineering. Elsevier Science: Burlington, 2012.

85. Romer, R. Fuel cell systems provide clean backup power in telecom applications worldwide. In Proceedings of the 2011 IEEE 33rd International Telecommunications Energy Conference (INTELEC), Amsterdam, The Netherlands, 9-13 October 2011.

86. Petrollese, M.; Cau, G.; Cocco, D.; Lucariello, M. Optimal generation scheduling for a hybrid stand-alone power system using renewable energy sources and hydrogen storage. In Proceedings of the 27th International Conference on Efficiency, Cost, Optimization, Simulation and Environmental Impact of Energy Systems, Turku, Finland, 15-19 June 2014.

87. Castañeda, M.; Cano, A.; Jurado, F.; Sánchez, H.; Fernández, L.M. Sizing optimization, dynamic modeling and energy management strategies of a stand-alone pv/hydrogen/battery-based hybrid system. Int. J. Hydrog. Energy 2013, 38, 3830-3845.

88. Brinkhaus, M.; Jarosch, D.; Kapischke, J. All year power supply with off-grid photovoltaic system and clean seasonal power storage. Sol. Energy 2011, 85, 2488-2496.

89. Li, C.-H.; Zhu, X.-J.; Cao, G.-Y.; Sui, S.; Hu, M.-R. Dynamic modeling and sizing optimization of stand-alone photovoltaic power systems using hybrid energy storage technology. Renew. Energy 2009, 34, 815-826.

90. Shabani, B.; Andrews, J. An experimental investigation of a pem fuel cell to supply both heat and power in a solar-hydrogen raps system. Int. J. Hydrog. Energy 2011, 36, 5442-5452.

91. Mancuso, V.; Alouf, S. Reducing costs and pollution in cellular networks. Commun. Mag. IEEE 2011, 49, 63-71.

92. Marsan, M.A.; Bucalo, G.; Di Caro, A.; Meo, M.; Zhang, Y. Towards zero grid electricity networking: Powering bss with renewable energy sources. In Proceedings of the 2013 IEEE International Conference on Communications Workshops (ICC), Budapest, Hungary, 9-13 June 2013; pp. 596-601. 
93. Budzisz, L.; Ganji, F.; Rizzo, G.; Marsan, M.A.; Meo, M.; Zhang, Y.; Koutitas, G.; Tassiulas, L.; Lambert, S.; Lannoo, B. Dynamic resource provisioning for energy efficiency in wireless access networks: A survey and an outlook. Commun. Surv. Tutor. IEEE 2014, 16, 2259-2285.

94. Suarez, L.; Nuaymi, L.; Bonnin, J.-M. An overview and classification of research approaches in green wireless networks. J. Wirel. Commun. Netw. 2012, 2012, 1-18.

95. Arnold, O.; Richter, F.; Fettweis, G.; Blume, O. Power consumption modeling of different base station types in heterogeneous cellular networks. In Proceedings of the 2010 Future Network and Mobile Summit, Florence, Italy, 16-18 June 2010; pp. 1-8.

96. Shen, Y.; Jiang, C.; Quek, T.Q.; Zhang, H.; Ren, Y. Device-to-device cluster assisted downlink video sharing - A base station energy saving approach. In Proceedings of the 2014 IEEE Global Conference on Signal and Information Processing (GlobalSIP), Atlanta, GA, USA, 3-5 December 2014; pp 108-112.

97. Jiang, C.; Zhang, H.; Ren, Y.; Chen, H.-H. Energy-efficient non-cooperative cognitive radio networks: Micro, meso, and macro views. Commun. Mag. IEEE 2014, 52, 14-20.

98. Holtkamp, H.; Auer, G.; Bazzi, S.; Haas, H. Minimizing base station power consumption. Sel. Areas Commun. IEEE J. 2014, 32, 297-306.

99. Lorincz, J.; Garma, T.; Petrovic, G. Measurements and modelling of base station power consumption under real traffic loads. Sensors 2012, 12, 4281-4310.

100. Kyuho, S.; Hongseok, K.; Yung, Y.; Bhaskar, K. Toward energy-efficient operation of base stations in cellular wireless networks. In Green communications, Jingsong, W.; Sundeep, R.; Honggang, Z., Eds.; CRC Press: Boca Raton, FL, USA, 2012; pp 435-474.

101. Koutroulis, E.; Kolokotsa, D.; Potirakis, A.; Kalaitzakis, K. Methodology for optimal sizing of stand-alone photovoltaic/wind-generator systems using genetic algorithms. Sol. Energy 2006, 80, 1072-1088.

102. Auer, G.; Giannini, V.; Gódor, I.; Skillermark, P.; Olsson, M.; Imran, M.A.; Sabella, D.; Gonzalez, M.J.; Desset, C.; Blume, O. Cellular energy efficiency evaluation framework. In Proceedings of Vehicular Technology Conference (VTC Spring), 2011 IEEE 73rd, Yokohama, Japan, 15-18 May 2011; IEEE: pp 1-6.

103. Tan, Y.; Meegahapola, L.; Muttaqi, K.M. A review of technical challenges in planning and operation of remote area power supply systems. Renew. Sustain. Energy Rev. 2014, 38, 876-889.

104. Graham, V.A.; Hollands, K.G.T. A method to generate synthetic hourly solar radiation globally. Sol. Energy 1990, 44, 333-341.

105. Masoum, M.A.; Mousavi Badejani, S.; Kalantar, M. Optimal placement of hybrid pv-wind systems using genetic algorithm. In Proceedings of the 2010 Innovative Smart Grid Technologies (ISGT), Gaithersburg, MD, USA, 19-21 January 2010; pp. 1-5.

106. Yazdanpanah Jahromi, M.A.; Farahat, S.; Barakati, S.M. Optimal size and cost analysis of standalone hybrid wind/photovoltaic power-generation systems. Civ. Eng. Environ. Syst. 2013, 31, 283-303.

107. Bajpai, P.; Dash, V. Hybrid renewable energy systems for power generation in stand-alone applications: A review. Renew. Sustain. Energy Rev. 2012, 16, 2926-2939.

108. Rajkumar, R.K.; Ramachandaramurthy, V.K.; Yong, B.L.; Chia, D.B. Techno-economical optimization of hybrid pv/wind/battery system using neuro-fuzzy. Energy 2011, 36, 5148-5153.

109. Yang, H.; Zhou, W.; Lu, L.; Fang, Z. Optimal sizing method for stand-alone hybrid solar-wind system with lpsp technology by using genetic algorithm. Sol. Energy 2008, 82, 354-367. 
110. Mellit, A. Ann-based ga for generating the sizing curve of stand-alone photovoltaic systems. $A d v$. Eng. Softw. 2010, 41, 687-693.

111. Ashhab, M.S.S. Optimization and modeling of a photovoltaic solar integrated system by neural networks. Energy Convers. Manag. 2008, 49, 3349-3355.

112. Mellit, A. Sizing of stand-alone photovoltaic power supply system based on genetic algorithm and neuro-fuzzy: Application for isolated areas. Int. J. Sustain. Energy 2008, 27, 49-60.

113. Xu, D.; Kang, L.; Chang, L.; Cao, B. Optimal sizing of standalone hybrid wind/pv power systems using genetic algorithms. In Proceedings of the 2005 Canadian Conference on Electrical and Computer Engineering, Saskatoon, SK, Canada, 1-4 May 2005; pp. 1722-1725.

114. Mellit, A.; Benghanem, M.; Hadj Arab, A.; Guessoum, A.; Moulai, K. Neural network adaptive wavelets for sizing of stand-alone photovoltaic systems. In Proceedings of the 2nd International IEEE Conference Intelligent Systems, Varna, Bulgaria, 22-24 June 2004; Volume 1, pp. 365-370.

115. Luna-Rubio, R.; Trejo-Perea, M.; Vargas-Vázquez, D.; Ríos-Moreno, G.J. Optimal sizing of renewable hybrids energy systems: A review of methodologies. Sol. Energy 2012, 86, 1077-1088.

116. Dufo-López, R.; Bernal-Agustín, J.L. Multi-objective design of pv-wind-diesel-hydrogen-battery systems. Renew. Energy 2008, 33, 2559-2572.

117. Mellit, A.; Benghanem, M.; Hadj Arab, A.; Guessoum, A. Modelling of sizing the photovoltaic system parameters using artificial neural network. In Proceedings of the 2003 IEEE International Conference on Control Applications (CCA 2003), Istanbul, Turkey, 23-25 June 2003; pp. 353-357.

118. Diaf, S.; Notton, G.; Belhamel, M.; Haddadi, M.; Louche, A. Design and techno-economical optimization for hybrid pv/wind system under various meteorological conditions. Appl. Energy 2008, 85, 968-987.

119. Yang, H.; Lu, L.; Zhou, W. A novel optimization sizing model for hybrid solar-wind power generation system. Sol. Energy 2007, 81, 76-84.

120. Bhave, A.G. Hybrid solar-wind domestic power generating system - a case study. Renew. Energy 1999, 17, 355-358.

121. Celik, A.N. A simplified model for estimating the monthly performance of autonomous wind energy systems with battery storage. Renew. Energy 2003, 28, 561-572.

122. Celik, A.N. The system performance of autonomous photovoltaic-wind hybrid energy systems using synthetically generated weather data. Renew. Energy 2002, 27, 107-121.

123. Celik, A. Optimisation and techno-economic analysis of autonomous photovoltaic-wind hybrid energy systems in comparison to single photovoltaic and wind systems. Energy Convers. Manag. 2002, 43, 2453-2468.

124. Tina, G.; Gagliano, S.; Raiti, S. Hybrid solar/wind power system probabilistic modelling for longterm performance assessment. Sol. Energy 2006, 80, 578-588.

125. Dufo-López, R.; Bernal-Agustín, J.L.; Mendoza, F. Design and economical analysis of hybrid pv-wind systems connected to the grid for the intermittent production of hydrogen. Energy Policy 2009, 37, 3082-3095.

126. Yang, H.; Wei, Z.; Chengzhi, L. Optimal design and techno-economic analysis of a hybrid solar-wind power generation system. Appl. Energy 2009, 86, 163-169.

127. Okundamiya, M.S.; Emagbetere, J.O.; Ogujor, E.A. Design and control strategy for a hybrid green energy system for mobile telecommunication sites. J. Power Sources 2014, 257, 335-343. 
128. Erdinc, O.; Uzunoglu, M. Optimum design of hybrid renewable energy systems: Overview of different approaches. Renew. Sustain. Energy Rev. 2012, 16, 1412-1425.

129. Dufo-López, R.; Bernal-Agustín, J.L.; Contreras, J. Optimization of control strategies for standalone renewable energy systems with hydrogen storage. Renew. Energy 2007, 32, 1102-1126.

130. Boonbumroong, U.; Pratinthong, N.; Thepa, S.; Jivacate, C.; Pridasawas, W. Particle swarm optimization for ac-coupling stand alone hybrid power systems. Sol. Energy 2011, 85, 560-569.

131. Wenmin, M.; Haijun, Z.; Wei, Z.; Zhaoming, L.; Xiangming, W. Mos-driven energy efficient power allocation for wireless video communications. In Proceedings of the 2012 IEEE Globecom Workshops (GC Wkshps), Anaheim, CA, USA, 3-7 December 2012; pp. 52-56.

132. Ekren, O.; Ekren, B.Y. Size optimization of a pv/wind hybrid energy conversion system with battery storage using simulated annealing. Appl. Energy 2010, 87, 592-598.

133. Anderson, H.R.; McGeehan, J.P. Optimizing microcell base station locations using simulated annealing techniques. In Proceedings of the 1994 IEEE 44th Vehicular Technology Conference, Stockholm, Sweden, 8-10 June 1994; pp. 858-862.

134. Fadaee, M.; Radzi, M.A.M. Multi-objective optimization of a stand-alone hybrid renewable energy system by using evolutionary algorithms: A review. Renew. Sustain. Energy Rev. 2012, 16, 3364-3369.

135. Niknam, T.; Taheri, S.I.; Aghaei, J.; Tabatabaei, S.; Nayeripour, M. A modified honey bee mating optimization algorithm for multiobjective placement of renewable energy resources. Appl. Energy 2011, 88, 4817-4830.

136. Mellit, A.; Kalogirou, S.A.; Drif, M. Application of neural networks and genetic algorithms for sizing of photovoltaic systems. Renew. Energy 2010, 35, 2881-2893.

137. Beccali, M.; Cellura, M.; Lo Brano, V.; Marvuglia, A. Forecasting daily urban electric load profiles using artificial neural networks. Energy Convers. Manag. 2004, 45, 2879-2900.

138. Jimenez-Fernandez, S.; Salcedo-Sanz, S.; Gallo-Marazuela, D.; Gomez-Prada, G.; Maellas, J.; Portilla-Figueras, A. Sizing and maintenance visits optimization of a hybrid photovoltaic-hydrogen stand-alone facility using evolutionary algorithms. Renew. Energy 2014, 66, 402-413.

139. Zhou, W.; Lou, C.; Li, Z.; Lu, L.; Yang, H. Current status of research on optimum sizing of standalone hybrid solar-wind power generation systems. Appl. Energy 2010, 87, 380-389.

140. Erdinc, O.; Uzunoglu, M. Recent trends in pem fuel cell-powered hybrid systems: Investigation of application areas, design architectures and energy management approaches. Renew. Sustain. Energy Rev. 2010, 14, 2874-2884.

141. Dorigo, M.; Stützle, T. Ant colony optimization: Overview and recent advances. In Handbook of metaheuristics, Gendreau, M.; Potvin, J.-Y., Eds.; Springer US: New York, NY, USA, 2010; Vol. 146, pp 227-263.

142. Yan, Q.; Toghiani, H.; Lee, Y.-W.; Liang, K.; Causey, H. Effect of sub-freezing temperatures on a pem fuel cell performance, startup and fuel cell components. J. Power Sources 2006, 160, 1242-1250.

143. Tajiri, K.; Tabuchi, Y.; Kagami, F.; Takahashi, S.; Yoshizawa, K.; Wang, C.-Y. Effects of operating and design parameters on pefc cold start. J. Power Sources 2007, 165, 279-286.

144. Zhang, G.; Kandlikar, S.G. A critical review of cooling techniques in proton exchange membrane fuel cell stacks. Int. J. Hydrog. Energy 2012, 37, 2412-2429. 
145. Kandlikar, S.G.; Lu, Z. Thermal management issues in a pemfc stack - a brief review of current status. Appl. Therm. Eng. 2009, 29, 1276-1280.

146. Kandlikar, S.G.; Lu, Z. Fundamental research needs in combined water and thermal management within a proton exchange membrane fuel cell stack under normal and cold-start conditions. J. Fuel Cell Sci. Technol. 2009, 6, 1-13.

147. Yin, H.; Guo, H.-f.; Lu, T. Study on ventilation cooling system for telecommunication base station. Energy Conserv. 2011, 1, 212-218.

148. Wei, C.; Liu, Z.-J.; Li, Z.-Y.; Qu, Z.-G.; Tao, W.-Q. Numerical study on some improvements in the passive cooling system of a radio base station. Numer. Heat Transf. Part A: Appl. 2012, 62, 319-335.

149. Garcia, M.P.; Cosley, M.R. Ambient air cooling of electronics in an outdoor environment. In Proceedings of the 26th Annual International Telecommunications Energy Conference, 2004 (INTELEC 2004), Chicago, IL, USA, 19-23 September 2004; pp. 437-441.

150. Nakao, M.; Hayama, H.; Uekusa, T. An efficient cooling system for telecommunication equipment rooms. In Proceedings of the 10th International Telecommunications Energy Conference, 1988 (INTELEC '88), 30 October-2 November 1988; pp. 344-349.

151. Therrien, D.; Riddoch, H. Telecom shelter cooling and control system. Google Patent US8770493 B2, 8 July 2014.

152. Choi, J.; Jeon, J.; Kim, Y. Cooling performance of a hybrid refrigeration system designed for telecommunication equipment rooms. Appl. Therm. Eng. 2007, 27, 2026-2032.

153. Maeda, Y.; Seshimo, Y.; Okazaki, T; Coe B. Study of a cooling system for the telecommunication base site. Ashrae Tran. 2005, 111, 746-755.

154. Tu, R.; Liu, X.-H.; Li, Z.; Jiang, Y. Energy performance analysis on telecommunication base station. Energy and Build. 2011, 43, 315-325.

155. Darwiche, A.-K.; Shaik, S. Air conditioning remote telecom enclosures. ASHRAE J. 2008, 50, 42-48.

156. Karasseferian, V.V.; Desjardins, R. Recovering the heat dissipated by the digital switching equipment. In Proceedings of the 1982 International Telecommunications Energy Conference (INTELEC 1982), Washington, DC, USA, 3-6 October 1982; pp. 374-378.

157. Flores, M.A.; Han, J.J.K. Base station heat management system. Google Patent US5934079 A, 10 August 1999.

158. Pell, D.J.; Sahraoui, M.; Zapach, T.G. Electronics enclosure for power electronics with passive thermal management. Google Patent US6084772 A, 4 July, 2000.

159. Gropper, J. 25 years of experience with closed cycle vapor turbogenerators as primary power source in remote telecommunications projects in russia and cis countries. In Proceedings of the 3rd International Telecommunications Energy Special Conference (TELESCON 2000), Dresden, Germany, 7-10 May 2000; pp. 203-207.

160. Dukhan, N.; Cress, M.; Cosley, M. Cooling and heating system for an equipment enclosure using a vortex tube. Google Patent US6401463 B1, 11 June, 2002.

161. Gianolio, G.; Rosso, I.; Mercante, L.; Pedrazzo, F.; Simonato, G.; Ceriani, F. Greenshelter for telecom applications a new generation of shelters for telecom applications integrating fuel cell electric backup and a new cooling approach. In Proceedings of the IEEE 30th International Telecommunications Energy Conference (INTELEC 2008), 14-18 September 2008; pp. 1-7. 
162. Cosley, M.; Garcia, M.; Teter, J. Thermal energy storage transfer system. Google Patent US7505269 B1, 17 March, 2009.

163. Samba, A.; Louahlia-Gualous, H.; Le Masson, S.; Nörterhäuser, D. Two-phase thermosyphon loop for cooling outdoor telecommunication equipments. Appl. Therm. Eng. 2013, 50, 1351-1360.

164. Settou, N.; Benmhidi, A. Passive cooling of telecom shelter using solar chimney with earth-air heat exchanger. Recent Adv. Energy Environ. Biol. Ecol. 2010, 134-138.

165. Zhang, Y.; Chen, Y.; Wu, J.; Meng, Q. Study on energy efficient envelope design for telecommunication base station in guangzhou. Energy Build. 2008, 40, 1895-1900.

166. Nakao, M.; Ohshima, K.; Jitsukawa, H. Thermal control wall for telecommunication equipment rooms. In Proceedings of the INTELEC, International Telecommunications Energy Conference, San Diego, CA, USA, 30 October-2 November 1988; pp. 280-284.

167. Dan, N.; Matti, K. Application of cfd technique in thermal design of a telecommunication base station. In Proceedings of the 9th International Flotherm User Conference, Orlando, FL, USA, 18-19 October 2000.

168. Schmidt, R.R.; Shaukatullah, H. Computer and telecommunications equipment room cooling: A review of literature. In Proceedings of the Eighth Intersociety Conference on Thermal and Thermomechanical Phenomena in Electronic Systems (ITHERM 2002), San Diego, CA, USA, 30 May-1 June 2002; pp. 751-766.

169. Hosseinzadeh, E.; Rokni, M.; Rabbani, A.; Mortensen, H.H. Thermal and water management of low temperature proton exchange membrane fuel cell in fork-lift truck power system. Appl. Energy 2013, 104, 434-444.

170. Ji, Y.; Wang, C.Y. Heating strategies for li-ion batteries operated from subzero temperatures. Electrochimica Acta 2013, 107, 664-674.

171. Lu, L.; Han, X.; Li, J.; Hua, J.; Ouyang, M. A review on the key issues for lithium-ion battery management in electric vehicles. J. Power Sources 2013, 226, 272-288.

172. Robertson, A.D.; West, A.R.; Ritchie, A.G. Review of crystalline lithium-ion conductors suitable for high temperature battery applications. Solid State Ion. 1997, 104, 1-11.

173. Zhang, J.; Ge, H.; Li, Z.; Ding, Z. Internal heating of lithium-ion batteries using alternating current based on the heat generation model in frequency domain. J. Power Sources 2015, 273, 1030-1037.

174. Islam, M.; Shabani, B.; Rosengarten, G.; Andrews, J. The potential of using nanofluids in pem fuel cell cooling systems: A review. Renew. Sustain. Energy Rev. 2015, 48, 523-539.

175. Liu, R.; Chen, J.; Xun, J.; Jiao, K.; Du, Q. Numerical investigation of thermal behaviors in lithium-ion battery stack discharge. Appl. Energy 2014, 132, 288-297.

176. Ge, S.; Wang, C.-Y. Characteristics of subzero startup and water/ice formation on the catalyst layer in a polymer electrolyte fuel cell. Electrochimica Acta 2007, 52, 4825-4835.

177. Gwak, G.; Ko, J.; Ju, H. Numerical investigation of cold-start behavior of polymer-electrolyte fuel-cells from subzero to normal operating temperatures-effects of cell boundary and operating conditions. Int. J. Hydrog. Energy 2014, 39, 21927-21937.

178. Kagami, F.; Ogawa, T.; Hishinuma, Y.; Chikahisa, T. Simulating the performance of a pefc at a temperature below freezing. Available online: https:/getinfo.de/de/suchen/id/ BLCP\%3ACN052966722/ (accessed on 1 September 2015). 
179. Pesaran, A.; Keyser, M.; Kim, G.-H.; Santhanagopalan, S.; Smith, K. Tools for designing thermal management of batteries in electric drive vehicles. U.S. Department of Energy: Golden, CO, USA, 2013.

180. Shabani, B.; Andrews, J.; Badwal, S. Fuel cell heat recovery, electrical load management, and the economics of solar-hydrogen systems. Int. J. Power Energy Syst. 2010, 30, 256.

181. Bruni, G.; Cordiner, S.; Mulone, V.; Giordani, A.; Savino, M.; Tomarchio, G.; Malkow, T.; Tsotridis, G.; Bodker, S.; Jensen, J.; et al. Fuel cell based power systems to supply power to telecom stations. Int. J. Hydrog. Energy 2014, 39, 21767-21777.

182. Lagorse, J.; Simões, M.G.; Miraoui, A. A multiagent fuzzy-logic-based energy management of hybrid systems. Ind. Appl. IEEE Trans. 2009, 45, 2123-2129.

183. Okundamiya, M.S.; Emagbetere, J.O.; Ogujor, E.A. Assessment of renewable energy technology and a case of sustainable energy in mobile telecommunication sector. Sci. World J. 2014, 2014.

184. Caisheng, W.; Nehrir, M.H. Power management of a stand-alone wind/photovoltaic/fuel cell energy system. Energy Convers. IEEE Trans. 2008, 23, 957-967.

185. Zhan, Y.; Wang, H.; Zhu, J. Modelling and control of hybrid ups system with backup pem fuel cell/battery. Int. J. Electr. Power Energy Syst. 2012, 43, 1322-1331.

186. Speirs, J.; Contestabile, M.; Houari, Y.; Gross, R. The future of lithium availability for electric vehicle batteries. Renew. Sustain. Energy Rev. 2014, 35, 183-193.

187. Song, L.; Niyato, D.; Han, Z.; Hossain, E. Wireless device-to-device communications and networks. Cambridge University Press: Cambridge, UK, 2015.

188. Jingjin, W.; Yujing, Z.; Zukerman, M.; Yung, E.K.N. Energy-efficient base-stations sleep-mode techniques in green cellular networks: A survey. Commun. Surv. Tutor. IEEE 2015, 17, 803-826.

189. Rengarajan, B.; Rizzo, G.; Ajmone Marsan, M. Energy-optimal base station density in cellular access networks with sleep modes. Comput. Netw. 2015, 78, 152-163.

190. Sun, X.; Zhang, Q.; Medina, M.A.; Liao, S. Performance of a free-air cooling system for telecommunications base stations using phase change materials (pcms): In-situ tests. Appl. Energy 2015, 147, 325-334.

191. Zhang, H.; Shao, S.; Xu, H.; Zou, H.; Tian, C. Free cooling of data centers: A review. Renew. Sustain. Energy Rev. 2014, 35, 171-182.

192. Zhang, P.; Wang, B.; Wu, W.; Shi, W.; Li, X. Heat recovery from internet data centers for space heating based on an integrated air conditioner with thermosyphon. Renew. Energy 2015, 80, 396-406.

193. Zhou, F.; Chen, J.; Ma, G.; Liu, Z. Energy-saving analysis of telecommunication base station with thermosyphon heat exchanger. Energy Build. 2013, 66, 537-544.

194. Han, L.; Shi, W.; Wang, B.; Zhang, P.; Li, X. Development of an integrated air conditioner with thermosyphon and the application in mobile phone base station. Int. J. Refrig. 2013, 36, 58-69.

195. Khodabandeh, R. Thermal performance of a closed advanced two-phase thermosyphon loop for cooling of radio base stations at different operating conditions. Appl. Therm. Eng. 2004, 24, 2643-2655.

(C) 2015 by the authors; licensee MDPI, Basel, Switzerland. This article is an open access article distributed under the terms and conditions of the Creative Commons Attribution license (http://creativecommons.org/licenses/by/4.0/). 